\title{
Comparative transcriptome analysis by Tilletia horrida infection in resistant and susceptible rice (Oryza sativa L.) male sterile lines reveals candidate genes and resistant mechanisms
}

\author{
Aijun Wang ( $\square$ ajwang6174@126.com ) \\ Sichuan Agricultural University \\ Desuo Yin \\ sichuan agriculture university \\ Xinyue Shu \\ sichuan agriculture university \\ Linxia Wang \\ sichuan agriculture university \\ Ping Li \\ sichuan agriculture university \\ Aiping Zheng \\ sichuan agriculture university
}

Research article

Keywords: Tilletia horrida; transcriptional analysis; flavonoid biosynthesis; plant-pathogen interaction, plant hormone signal transduction, transcriptional factor

Posted Date: October 18th, 2019

DOI: https://doi.org/10.21203/rs.2.16204/v1

License: (a) (i) This work is licensed under a Creative Commons Attribution 4.0 International License. Read Full License 


\section{Abstract}

Background Rice kernel smut (RKS), caused by the basidiomycete fungus Tilletia horrida, is one of the most devastating diseases affecting the production of male sterile lines of rice ( Oryza sativa) worldwide. However, molecular mechanisms of resistance to T. horrida have not yet been explored. Results In the present study, analysis of the amount of T. horrida biomass in rice kernels and RNA sequencing (RNA-Seq) analysis of rice male sterile lines resistant and susceptible to RKS (Jiangcheng 3A and 9311A, respectively) were conducted after T. horrida infection. Transcriptomic analysis showed that 9, 840 and 7, 902 differentially expressed genes (DEGs) were observed in Jiangcheng3A and 9311A, respectively, after T. horrida inoculation, compared with the control. KEGG analyses of DEGs revealed that cutin, suberine and wax biosynthesis, flavonoid biosynthesis, glutathione metabolism, tyrosine metabolism, and biosynthesis of unsaturated fatty acids were enriched by T. horrida inoculation in Jiangcheng $3 \mathrm{~A}$; however, not significantly enriched in 9311A. Furthermore, the DEGs related to plant-pathogen interaction, plant hormone signal transduction, and transcriptional factor genes were identified in both rice male sterile lines.Conclusions This is the first comparative transcriptome analysis of two rice genotypes with different responses to $\mathrm{T}$. horrida infection, revealing DEGs with potentially important roles in defense against $\mathrm{T}$. horrida infection. Ours results will serve as a strong foundation for developing effective strategies for T. horrida -resistance breeding.

\section{Background}

Rice (Oryza sativa) is the most important food crop, providing approximately $20 \%$ of the dietary energy supply across the world [1, 2]. High-yielding rice and hybrid rice cultivars have been cultivated to meet the increasing demand for food. Male sterile lines of rice play an important role in the yield of hybrid seed production. Rice kernel smut (RKS), a major disease affecting hybrid rice production, is caused by a biotrophic soil-borne basidiomycete fungus Tilletia horrida, which infects floral organs of rice male sterile lines and affects both yield and quality of hybrid seed by producing masses of dark powdery teliospores $[3,4,5]$. This disease has an annual incidence of $40-60 \%$ in hybrid rice fields, leading to a $5-20 \%$ decrease in rice yield [6]. In Pakistan and China, the disease incidence of RKS in hybrid rice fields is $87 \%$ and $100 \%$, respectively [7]. Despite the high yield losses caused by RKS, there is no effective method to prevent this disease, and its control relies mainly on the use of chemical fungicides [8].

Smuts fungi are widespread in soil and seeds of host plants. To data, 80 genera of smut fungi $(4,200$ species) have been morphologically characterised. All of these fungi species are parasitic on higher plants such as rice, barley (Hordewn vulgare), maize (Zea mays), sugarcane (Saccharum officinarum) and wheat (Triticum aestivum) [9]. The teliospore balls of T. horrida show strong adaptability, and can survive for more than 1 year in the soil, and for more than 3 years in rice seeds infected at the flowering stage $[6,8]$. In addition to rice, $T$. horrida is also known to infect wild rice and certain weeds; this facilitates the spread of the fungus to healthy rice plants at the flowering stage. 
In rice, numerous quantitative trait loci (QTLs) or genes responsible for resistance to diseases such as bacterial sheath blight and rice blast have been identified, and several genes have been successfully used for breeding cultivars resistant these diseases $[10,11,12,13]$. However, studies on the interactions between $T$. horrida and rice genotypes have been hampered by the scarcity of resistant rice cultivars, difficulty in inoculation, and gene-environment interactions complicating measurements of plant susceptibility. Over the past two decades, researchers have predominantly focused on the process of pathogen infection, morphological characteristics and evolutionary biology of the pathogen, and mechanism of infection. However, little is known about the molecular mechanisms of resistance to RKS, and no genes or QTL underlying resistance to T. horrida have been reported to data $[14,15]$.

Recent advancements in sequencing technologies have enabled the investigation of pathogenesis, hostdefence responses, and host-pathogen interactions at the molecular level [16]. RNA-Seq is an emerging technology for transcriptome sequencing, and its high-throughput ability has accelerated genomic research and gene function analysis [17]. Many genes related to pathogen resistance and stress tolerance have been identified in rice, wheat, maize, and Arabidopsis thaliana via transcriptome analysis $[18,19,20$, 21]. Additionally, numerous genes imparting resistance to rice sheath blight have been identified using transcriptome sequencing, and the associated resistance mechanisms have been explored [22]. Transcriptome analysis has also revealed the molecular mechanisms of drought resistance in rice [23].

In this study, we used RNA-Seq to identify rice genes showing significant changes in expression in response to $T$. horrida infection during the early stages of infection. Rice genotypes used in this study included Jiangcheng $3 \mathrm{~A}$ and $9311 \mathrm{~A}$, which are resistant and susceptible to T. horrida, respectively. Gene expression in these lines was analysed at $8,12,24,48$, and $72 \mathrm{~h}$ after $T$. horrida inoculation using Illumina RNA-Seq analysis, followed by quantitative real-time PCR (qRT-PCR) to identify differentially expressed genes (DEGs) potentially responsible for the resistance phenotype of Jiangcheng 3A against $T$. horrida. The results of this study will enhance our understanding of the basal differences in gene expression between these resistance and susceptible rice genotypes. This is the first report of rice resistance mechanisms effective against $T$. horrida using comparative transcriptome profiling.

\section{Methods}

\section{Plant growth conditions and pathogen inoculation}

The resistance phenotype of Jiangcheng $3 \mathrm{~A}$ to $T$. horrida infection has been previously identified via inoculation tests from 2014-2016 [15], 9311A is a considered a highly susceptible standard. They were provided by the Department of Food Crop Research Institute of Hubei Academy of Agricultural Science. The $T$. horrida isolate JY-521, a virulent strain with a sequenced the genome, was used for plant inoculations and separating and preserving by the Department of Rice Research Institute of Sichuan Agricultural University [14]. Monoconidial cultures of $T$. horrida were grown in potato dextrose broth in an incubator at $28^{\circ} \mathrm{C}$ for 7 days on a shaker at $150 \mathrm{rpm}$. Approximately $1 \mathrm{~mL}$ of conidial suspension $\left(10^{6}\right.$ conidia $\mathrm{mL}^{-1}$ ) was injected into the immature kernels of field grown rice plants at the booting stage, i.e. 5- 
7 days before heading. Inoculations were performed in the late afternoon to facilitate infection. The biomass of $T$. horrida spores in rice kernels was quantified to determine the sampling time point. Panicles were harvested at $8,12,24,48$, and $72 \mathrm{~h}$ post inoculation. Kernels of each cultivar inoculated with $1 \mathrm{~mL}$ of sterilized distilled water for $8 \mathrm{~h}$ served as a control (infection $0 \mathrm{~h}$ ). Three biological replicates of each sample were collected, immediately frozen in liquid nitrogen, and stored at $-80^{\circ} \mathrm{C}$ for RNA isolation.

\section{qRT-PCR analysis}

First strand cDNA was synthesized from total RNA using the Transcriptor First-Strand cDNA Synthesis Kit (Roche, Indianapolis, IN, USA). The cDNA samples were then subjected to qRT-PCR on a Bio-Rad CFX96 Real-Time PCR System (Foster City, CA, USA), according to the manufacturer's instructions. The PCR reactions were prepared in a $20 \mu \mathrm{L}$ volume, containing $3 \mu \mathrm{L} \mathrm{cDNA}$ and $0.8 \mu \mathrm{L}$ each of the forward and reverse gene specific primers. Each PCR was replicated three times. The Ubiquitin (UBQ) gene was used as an internal control for data normalization. Gene expression levels were calculated using the $2^{-\Delta \Delta C t}$ method. The biomass of $T$. horrida spores in rice kernels was quantified based on the abundance $18 \mathrm{~S}$ rRNA of $T$. horrida relative to that of rice [24]. Primers used for qRT-PCR are listed in Additional file 1: Table S1.

\section{RNA-Seq library preparation, Illumina sequencing, and read-mapping}

RNA-Seq libraries were constructed using NEBNext ${ }^{\circledR}$ Ultra ${ }^{\text {TM }}$ RNA Library Prep Kit for Illumina ${ }^{\circledR}$ (NEB, USA), according to the manufacturer's instructions, and unique index codes were added to each sample. RNA samples were sent to Beijing Novogene Biological Technology Co., Ltd for cDNA library construction and Illumina sequencing (HiSeq TM 2500, San Diego, NEB, USA). Sequencing was performed using Illumina Hiseq platform to generate 125 bp paired-end reads. Reads with low quality score and those containing adaptor sequences and stretches of -Ns were removed from the raw data. The reference genome of Nipponbare rice and gene model annotation files (Rice Annotation Project) were downloaded directly from the rice genome website (ftp://ftp.ensemblgenomes. org/ pub/ plants/ release_36/fasta/ oryza_indica/ $\mathrm{dna} /$ ). Index of the reference genome was built using Bowtie v2.2.3, and paired-end reads were aligned to the reference genome using TopHat v2.0.12 $[25,26,27]$. The number of reads mapped to each gene were counted using HTSeq v0.6.1 [28]. Then, the number of fragments per kilobase of transcript sequence per million (FPKM) of each gene was calculated based on the length of the gene and number of read counts mapped to that gene.

\section{Differential expression analysis}

Differential expression analysis of two conditions (three biological replicates per condition) was performed in R using DESeq package (v1.18.0) [29]. The DESeq method provides statistical routines for determining differential expression in digital gene expression data using a model based on negative binomial distribution. The resulting P-values were adjusted using the Benjamini and Hochberg's approach for controlling the false discovery rate (FDR). Genes with adjusted $\mathrm{P}<0.05$ were designated as differentially expressed [30]. 


\section{Series-clustered analysis}

A total of 4729 DEGs co-expressed in the two rice male sterile lines were classified into 24 clustered profiles based on the trend observed in gene expression using the Short Time-series Expression Miner (STEM) software [31]. The clustered profiles with $P \leq 0.05$ were considered as statistically significant. Then, DEGs in all or each profile were subjected to Gene Ontology (G0) and Kyoto Encyclopedia of Genes and Genomes (KEGG) pathway enrichment analyses. Based on the hypothesis test of P-value calculation and FDR correction [30], the $\mathrm{GO}$ terms or pathways with q-value $\leq 0.05$ were defined as significantly enriched.

\section{GO and KEGG enrichment analysis of DEGs}

GO enrichment analysis of the DEGs was performed in R using the GOseq package, after correcting for gene length bias [32, 33]. $\mathrm{GO}$ terms with adjusted $\mathrm{P}<0.05$ were considered significantly enriched. The KEGG database enables understanding the high-level functions and utilities of biological systems, such as the cell, organism and ecosystem, using molecular information, especially large-scale molecular datasets generated by genome sequencing and other high throughput experimental technologies (http://www.genome.jp/kegg/). The statistical enrichment analysis of DEGs in KEGG pathways was performed The using the KOBAS software [34, 35].

\section{Results}

\section{Quantification of T. horrida biomass in resistant and susceptible rice male sterile lines}

We have previously shown that the rice male sterile line Jiangcheng $3 \mathrm{~A}$ is resistant to $T$. horrida, whereas the rice male sterile cultivar 9311A is susceptible [15]. To confirm the response of Jiangcheng $3 \mathrm{~A}$ and 9311A to $T$. horrida infection, we infected both these cultivars with $T$. horrida at the booting stage (3-5 days before heading) and quantified pathogen growth in immature kernels over an infection time point. After 31 days of infection, 95\% of 9311 A panicles contained soft and hollow grains covered with a dark powdery mass of spores, and an average of 17.3 grains were infected per panicle (Fig. 1a, C). By contrast, only $3 \%$ of Jiangcheng $3 \mathrm{~A}$ grains were diseased, and only 2.1 kernels were infected per panicle. Thus, lower disease incidence observed in the rice male sterile cultivar Jiangcheng $3 \mathrm{~A}$ confirmed that it is resistant to T. horrida infection (Fig. 1b, c). To further reveal differences infection between the two rice male sterile cultivars in response to $T$. horrida infection and determine the ideal time points for transcriptome sequencing, we quantified the relative amount of fungal biomass in immature kernels of Jiangcheng $3 \mathrm{~A}$ and $9311 \mathrm{~A}$ using qRT-PCR during early stages of infection. Spores of $T$. horrida were detected in both cultivars at $8 \mathrm{~h}$ after infection. However, the biomass of $T$. horrida in immature kernels of 9311A continued to increase at a higher rate than in immature kernels of Jiangcheng $3 \mathrm{~A}$; at $48 \mathrm{~h}$, the $T$. horrida biomass in 9311A kernels was 2-fold greater than that in Jiangcheng 3A kernels (Fig. 1d).

\section{RNA-Seq analysis of rice male sterile lines}


To investigate changes in gene expression levels during the early infection stages, we conducted RNA-Seq analysis of Jiangcheng $3 \mathrm{~A}$ and $9311 \mathrm{~A}$ kernels at $8,12,24,48$, and $72 \mathrm{~h}$ post inoculation, with three biological replicates per time point. RNA-Seq analysis of all 36 samples generated 294.78 GB data, and 1, $965,147,576$ clean reads were obtained after quality trimming and adaptor removal (Additional file 2: Table S2). Across all 36 samples, the ratio of total mapped reads varied from $76.68-88.62 \%$, and that of unique mapped reads varied from 75.62-87.65\% (Additional file 3: Table S3). We performed correlation analysis of expression levels among the three replicates of each sample to assess the reliability of RNASeq data. Heat map of the correlation coefficients $\left(R^{2}\right)$ of all 36 transcriptome samples shown in Additional file 4: Fig. S1. Overall, a high correlation $\left(R^{2}>0.8\right)$ was detected among biological replicates of each RNA-Seq sample at each time point.

\section{Differential expression of genes in T. horrida inoculated Jiangcheng 3A and 9311A kernels}

To identify genes involved in resistance to $T$. horrida, we compared changes in gene expression between resistance male sterile line Jiangcheng $3 \mathrm{~A}$ and susceptible male sterile line $9311 \mathrm{~A}$ at different time points. We detected a total of 17, 742 DEGs in both the rice male sterile lines of which 9, 840 and 7, 902 DEGs were observed in Jiangcheng3A and 9311A, respectively (Fig. 2a). Among these DEGs, 4, 729 DEGs were shared by the two rice male sterile lines at different time points (Additional file 5: Table S4), and comparing these two groups, at $8,12,24,48$, and $72 \mathrm{~h}$ post inoculation, there are $332,992,82,852$, and 4 , 246 DEGs were shared in both cultivars, respectively (Fig. 2b-f). Furthermore, following T. horrida inoculation, the number of up-regulated genes in Jiangcheng $3 \mathrm{~A}$ kernels was significantly higher than that in 9311A kernels at the early infection time points. For example, at $8 \mathrm{~h}, 2,289 \mathrm{DEGs}(1,251$ up-regulated, and 1,038 down-regulated) were detected in Jiangcheng 3A kernels, compared with 1,617 DEGs (52 upregulated, and 1,565 down-regulated) in 9311A kernels (Fig. 2a). The number of DEGs in Jiangcheng 3A kernels was the highest at $72 \mathrm{~h}$ post inoculation ( $9,026 \mathrm{DEGs} ; 4,226$ up-regulated, and 4,800 downregulated), which was higher than the number of DEGs in 9311A kernels at the same time point $(5,737$ DEGs, 2, 275 up-regulated, and 3, 462 down-regulated) (Fig.2a). We further performed the trend analysis of 4, 729 common DEGs in two male sterile lines, and these genes were significantly enriched in 24 and 22 profiles in 9311A and Jiangcheng 3A kernels, respectively (Fig. 3a, c). The number of DEGs in profile 23 (sustained up regulation) and profile 0 (sustained down regulation) was most in both male sterile lines (Fig. 3a, c).

\section{Annotation and function classification of DEGs in two male sterile lines}

To identify whether these DEGs in both male sterile lines were significantly associated with a specific biological process, molecular function, or cellular component, $G O$ analyses of DEGs identified in each group (K8vsK0, K12vsK0, K24vsK0, K48vsK0, and K72vsK0; G8vsG0, G12vsG0, G24vsG0, G48vsG0, and G72vsG0) were performed, and the top $30 \mathrm{GO}$ enrichment terms were listed (Additional file 6 and 7: Table $\mathrm{S} 5$ and S6). For cellular component category, $35 \mathrm{GO}$ terms were enriched at five inoculation time points of Jiangcheng $3 \mathrm{~A}$, while $27 \mathrm{GO}$ terms were enriched in 9311A. Amongst these, $21 \mathrm{GO}$ terms were enriched in both the genotypes, $14 \mathrm{GO}$ terms namely DNA packaging complex, nuclear chromatin, protein-DNA 
complex, nucleosome, nuclear chromosome part, cytosolic ribosome, ribosome, ribosomal subunit, cytosolic part, non-membrane-bounded organelle, intracellular non-membrane-bounded organelle, ribonucleoprotein complex, large ribosomal subunit, and cytosolic large ribosomal subunit were unique enriched in Jiangcheng 3A. The molecular function category was enriched with 17 and $24 \mathrm{GO}$ terms in at least any of the inoculation time points of Jiangcheng $3 \mathrm{~A}$ and $9311 \mathrm{~A}$, respectively. Both the genotypes showed 12 common GO terms enrichment during the T. horrida inoculation. Carbohydrate binding, metal ion binding, urea transmembrane transporter activity, structural constituent of ribosome, and structural molecule activity molecular function were only enriched during the inoculation period in Jiangcheng $3 \mathrm{~A}$. In biological process category, $20 \mathrm{GO}$ terms, involve in polysaccharide metabolic process, cell wall modification, photosynthesis, pectin catabolic process, galacturonan metabolic process were enriched in both male sterile lines.

We further identified specific function of 4,729 common DEGs using GO enrichment analysis. For DGEs in profile 23, response to stimulus, developmental process, growth, and immune system process were enriched in both male sterile lines. These $\mathrm{GO}$ terms enriched suggest the general response or basic roles in the response to T. horrida. However, transcription factor activity was highly enriched in Jiangcheng $3 \mathrm{~A}$, but not in 9311 A (Fig. 3b, d). For DEGs in Profile 0, GO enrichment analysis showed that the genes enriched in profile 0 were related to transporter activity and signal transducer activity in the two rice cultivars (Fig. 3b, d). These two GO terms enrichment showed the down-regulated genes might cut off the inflow of nutrition to T. horrida [36].

\section{Analysis of metabolic pathways after T. horrida inoculation}

Resistance to T. horrida is the result of a common effect of multiple genes, which play roles in certain biological processes by interacting with each other [37]. Pathway enrichment analysis of DEGs in both rice male sterile lines based on the KEGG database was performed, and the significantly enriched pathways are listed in Supplementary Table S7 and S8. Among these, 17 pathways, include photosynthesis-antenna proteins, phenylpropanoid biosynthesis, biosynthesis of secondary metabolites, phenylalanine metabolism, cysteine and methionine metabolism, terpenoid backbone biosynthesis, carotenoid biosynthesis, photosynthesis, plant-pathogen interaction, tyrosine metabolism, plant hormone signal transduction, pentose and glucuronate interconversions, diterpenoid biosynthesis, starch and sucrose metabolism, ribosome, carbon fixation in photosynthetic organisms, and galactose metabolism were significantly enriched by $T$. horrida inoculation in both rice male sterile lines; However, pathways specifically enriched in resistance male sterile line Jiangcheng 3A by T. horrida inoculation include cutin, suberine and wax biosynthesis, flavonoid biosynthesis, glutathione metabolism, tyrosine metabolism, and biosynthesis of unsaturated fatty acids (Additional file 8 and 9: Table S7 and S8).

\section{DEGs involve in plant-pathogen interaction}

Plants employ two types of innate immune responses against invading pathogens: pathogen-associated molecule patterns (PAMPs) first layer of immunity and effector-triggered immunity (ETI) second layer of immunity [38]. ETI is based on the recognition of pathogen-secreted effectors by plant-specific resistance 
proteins [39]. We further analysis the DEGs involve in plant-pathogen interaction based on metabolic pathways analysis. In rice plants inoculated with T. horrida, 106 and 75 DEGs were found to be associated with plant-pathogen interaction in Jiangcheng 3A and 9311A, respectively (Additional file 10: Table S9). Among them, 67 were common to both rice cultivars, and 39 were unique to Jiangcheng $3 \mathrm{~A}$ (Supplementary Table S9 and Fig. 4a). The 67 common plant-pathogen interaction genes included gene encoding calcium/calmodulin dependent protein kinases, calmodulin, mitogen-activated protein kinase, and several heat shock protein. Jiangcheng $3 A$ showed expression of 39 unique plant-pathogen genes encoding plant chitin-binding proteins, JASMONATE ZIM-DOMAIN (JAZ) proteins, F-box proteins (Jasmonic acid receptor), disease resistance protein RPM1, NB-ARC/LRR disease resistance proteins, and serine/threonine protein kinases.

\section{DEGs involved in plant hormone signal transduction}

Once fungal effectors overcome the plant defence mechanism, plant resistance response becomes ineffective. In addition to the production of early signal molecules induced by pathogen infection, elicitor signals are frequently increased via the secretion of secondary signal molecules, such as ethylene (ET), salicylic acid (SA) and jasmonic acid (JA) [40]. Therefore, the DEGs related to plant hormone signal transduction were chosen for further analysis. A total of 92 and 81 DEGs were found to be associated with plant hormone signal transduction in Jiangcheng 3A and 9311A, respectively (Additional file 11: Table S10), and more than half of all these genes were common to both rice cultivars, there are seven DEGs were involved in the JA signaling pathway, including six jasmonatezim-domain (JAZ) genes and one jasmonyl-L-isoleucine synthase gene (OsJAR2); two DEGs related to the SA signaling pathway, including a key regulation factor of SA mediated disease resistance NPR1-like gene OsNPR1 and TGA gene OsNIF1; three DEGs related to the ET signaling pathway, including one ET receptor gene, two ET-insensitive genes. In addition, abscisic acid (ABA) signaling pathway-related genes, such as protein phosphatase $2 \mathrm{C}$ (PP2C) and stress-activated protein Kinase genes, pyrabactin resistance-like abscisic acid receptor genes, and bZIP transcription factor; auxin (AUX) signaling pathway-related genes, including small auxin upregulated RNA genes, indole-3-acetic acid-amido synthetase gene, and Aux/IAA genes were found in our results. Furthermore, we also found 39 DGEs associated with plant hormone signal transduction were unique to Jiangcheng 3A (Fig. 4b). Among these genes, one gibberellin (GA) signaling pathway-related gene OsGAI and three cytokinin (CTK) signaling pathway-related genes OsRR6, OsRR4, and OsRR1 were found. This result showed that GA and CTK signaling pathway may play important role in regulated of $T$. horrida resistant.

\section{Transcriptional factors (TFs) identified from DEGs}

TFs play a key role in plant defence responses [41]. A total of 760 and 647 TFs were identified from the DEGs using the plant TF database PlantTFDB version 4.0 (http://planttfdb.cbi.pku.edu.cn/) in Jiangcheng $3 \mathrm{~A}$ and $9311 \mathrm{~A}$, respectively (Fig. 5a). Interestingly, compared with the control conditions, 89 up-regulated and 74 down-regulated TF genes were identified in inoculated Jiangcheng $3 \mathrm{~A}$ kernels, while 8 up-regulated and 90 down-regulated TF genes were identified in inoculated $9311 \mathrm{~A}$ at $8 \mathrm{~h}$ (Fig. $5 \mathrm{~b}$ ). At $12 \mathrm{~h}$, these numbers changed to 78 up-regulated and 71 down-regulated TF genes in Jiangcheng $3 A$, and 122 up- 
regulated, 142 down-regulated TF genes in 9311A (Fig. 5c). Although most of the TF genes exhibiting altered expression after $T$. horrida infection were common to both male sterile lines, some were unique to Jiangcheng $3 \mathrm{~A}$.

\section{Validation of DEGs by qRT-PCR}

To verify the RNA-Seq data, randomly selected 21 genes for validation using qRT-PCR, included encoding rice pathogenesis-related proteins (PR1a, PR1b, and PR10a), WRKY TFs (OsWRKY24, OsWRKY31, and OsWRKY70) and proteins potentially involved in resistance to T. horrida, such as OsSGT1, disease resistance protein RPM1 (Os01g0788500), NB-ARC/LRR disease resistance protein (Os04g0514600), Os4CL5, OsCML12, OsICS1, OsCATC, OsMKK1, plant chitin-binding protein (Os03g0133400), DPW, ONI3, PAL (Os05g0427400), cinnamoyl-CoA reductase (Os08g0441500), and heat shock protein (Os08g0487800 and Os09g0482400). The threshold cycle (Ct) values of each gene were normalized relative to those of the UBQ gene (internal control; Supplementary Fig. S2). The relative expression patterns of these gene determined using qRT-PCR analysis were compared with Illumina RNA-Seq data (Fig. 6; Additional file 12: Fig. S2). Results showed that qRT-PCR data was consistent with that of Illumina data, confirming the reliability of Illumina RNA-Seq data (Fig. $6 ; \mathrm{R}^{2}>0.82$ ).

\section{Discussion}

\section{RNA sequencing and DEGs in response to T. horrida}

RKS caused by the fungus T. horrida, is the most the most widespread disease occurred in many field of hybrid seed produce, caused large yield lose. However, little information is known about the resistance pathways for T. horrida. As our previously reported, the rice male sterile line Jiangcheng $3 \mathrm{~A}$ was highly resistant to $T$. horrida, and displayed consistent results between inoculation experiments carried out in 3 years [15]. We further chose two male sterile lines, Jiangcheng $3 \mathrm{~A}$ and $9311 \mathrm{~A}$, as resistance and susceptible varieties, and performed comparative transcriptome analysis of different inoculation time points. Main aim was identify key pathway and genes involved in the resistant for $T$. horrida. Further, comparative analysis of DEGs of Jiangcheng 3A and 9311A revealed 4, 729 DEGs were commonly involved both rice male sterile lines, when we analysis the expression profile of these common 4, 729 DEGs of both the genotypes, numbers of DEGs in sustained up regulation and sustained down regulation was more compared to others expression profile.

For 9, 840 DEGs in Jiangcheng 3A, there are 5, 074 up-regulated and 4, 766 down-regulated, account for $51.57 \%$ and $48.43 \%$ of all DEGs, respectively; for 7, 902 DEGs in $9311 \mathrm{~A}, 3,365$ up-regulated and 4,537 down-regulated, account for $42.58 \%$ and $57.42 \%$ of all DEGs, respectively. This result showed that resistance male sterile line Jiangcheng $3 \mathrm{~A}$ has the higher percentage of genes up-regulated during the course of $T$. horrida inoculation, and suggests that these up-regulated genes may confer resistance to Jiangcheng $3 \mathrm{~A}$ during $T$. horrida inoculation. Our results were different from Teqing and Lemont, in which the number of up-regulated DEGs were more in Lemont (susceptible rice cultivar) than in TeQing (moderately resistant rice cultivar) after Rhizoctonia solani inoculation, probably due to difference of rice 
response inoculation of necrotrophic ( $R$. solani) and biotrophic (T. horrida) fungus [22]. Interestingly, upon exposure to low temperature stress, in cold tolerant variety were present higher percentage of genes upregulated than in cold susceptible variety [42]. In addition, at early (8 h) and late inoculation stages (72 h), more number of genes were participated the pathway of resistant to T. horrida in Jiangcheng $3 \mathrm{~A}$ compared with 9311A, indicated that primary pathogen colonization may be occurred in $8 \mathrm{~h}$, and the pathogen then established re-infection, causing the degree of infection to be enhanced at $72 \mathrm{~h}$.

\section{Functional characterization of DEGs}

For GO enrichment analysis, some common terms were enriched in both male sterile lines; however, there are some terms, such as nuclear chromatin, protein-DNA complex, nucleosome, nuclear chromosome part, cytosolic ribosome, ribosome, ribosomal subunit, cytosolic part, non-membrane-bounded organelle, intracellular non-membrane-bounded organelle, ribonucleoprotein complex, carbohydrate binding, metal ion binding, urea transmembrane transporter activity, structural constituent of ribosome, and structural molecule activity molecular function, were unique enriched in resistant male sterile line Jiangcheng 3A. We speculated that genotype that lacks these functions may be susceptible to $T$. horrida.

At 8 and $12 \mathrm{~h}$ as early infection times, a very high number of DEGs were enriched in hydrolase activity, hydrolyzing 0-glycosyl compounds, hydrolase activity, acting on glycosyl bonds, cation homeostasis, photosynthetic electron transport chain, response to radiation, and plastoglobule in Jiangcheng $3 \mathrm{~A}$ as compared to $9311 \mathrm{~A}$. During $24-72 \mathrm{~h}$ of $T$. horrida inoculation as late infection times, similar to early response DEGs, more DEGs were enriched under T. horrida infection. In this response phase, there are 86 terms enrichment in Jiangcheng 3A; however, 9311A was enriched in 60 terms, such as carbohydrate metabolic process, ion transport, cation transport, urea transmembrane transporter activity, peptide biosynthetic process, amide biosynthetic process, and regulation of catalytic activity were unique enriched in Jiangcheng $3 \mathrm{~A}$; indicated that there are more $\mathrm{GO}$ terms involve in resistant variety and these terms may play an important role for ability of Jiangcheng $3 A$ resistant to $T$. horrida.

\section{Key pathway resistance to $T$. horrida in rice}

KEGG analysis of DEGs showed that cutin, suberine and wax biosynthesis, flavonoid biosynthesis, tyrosine metabolism, glutathione metabolism, and biosynthesis of unsaturated fatty acids were only enriched in Jiangcheng 3A. Flavonoid and tyrosine ammonialyases play important roles in plant defence early during infection [43]. In addition, glutathione and some unsaturated fatty acids were also participates in signaling of plant defense against biotic and abiotic stresses [44]. These results indicated that these four pathways may play important role for ability of Jiangcheng $3 \mathrm{~A}$ resistance T. horrida.

A total of 6 DEGs were found to be associated with flavonoid biosynthesis. Among them, including two caffeoyl-CoA 0-methyltransferase genes, two cytochrome P450 genes and one leucoanthocyanidin reductase genes, and one transferase family protein (Table 1). Former reports showed that caffeoyl-CoA 0-methyltransferase gene may involve in regulation of lignin and other metabolites of the phenylpropanoid pathway and can enhance the multiple pathogens resistance of host plants [45]. In our 
results, two caffeoyl-CoA O-methyltransferase genes, Os08g0498100 and Os09g0481400 were sustained up-regulation in Jiangcheng 3A kernels after T. horrida inoculated; however in 9311A, only Os08g0498100 was up-regulation at $24 \mathrm{~h}$ after $T$. horrida inoculated (Table 1). Therefore, we speculate that these two genes were involved in pathway of $T$. horrida resistance. Proanthocyanidins are the polyphenolic compounds synthesized via the flavonoid biosynthetic pathway and play a key role in defence against pathogens [46]. Leucoanthocyanidin reductase is a key enzyme of biosynthesis of proanthocyanidins, can converting leucocyanidin to catechin [46]. Leucoanthocyanidin reductase gene Os04g0630800, was sustained up-regulation in both male sterile lines after $T$. horrida inoculated; however, the gene expression levels ( $\log _{2}$ FPKM) was higher in Jiangcheng $3 \mathrm{~A}$ than in 9311 A at $8 \mathrm{~h}$ (Table 1).

Plant cutin and wax are important extracellular hydrophobic substances that prevent the entry of pathogens into host cells [47]. In this study, two cutin, suberine and wax biosynthesis-related genes ONI3 and DPW were identified with up-regulation in the Jiangcheng 3A (Table 1). Expression levels of ONI3 and DPW increased following $T$. horrida infection were happen in 8 , suggesting that cutin and wax are required for protecting rice plants from the invading pathogens during the early stages of infection. In sum, we carefully concluded that Jiangcheng 3A kernels are capable of preventing $T$. horrida infection enhancing cell wall keratinization and by synthesising more secondary metabolites early during infection.

Moreover, there are six biosynthesis of unsaturated fatty acids-related genes were up-regulation in Jiangcheng $3 \mathrm{~A}$, including one oxidoreductase, two acyl-desaturase, one plastid $\omega-3$ desaturase, and two microsomal $\Delta 12$-fatty acid desaturase genes (Table 1 ). Furthermore, four up-regulation genes were involved in the tyrosine metabolism, including one nicotianamine aminotransferase gene, one tyrosine decarboxylase gene, and two dehydrogenase genes. In addition, there were ten up-regulation genes related to glutathione metabolism, including one spermidine synthase gene, one RNRS1 homolog gene, one large subunit of ribonucleotide reductase gene and one glucose-6-phosphate 1-dehydrogenase gene, one dehydrogenase gene, one L-ascorbate peroxidase 4 gene, one glutathione reductase gene, and three glutathione S-transferase genes. Among these genes, eight were present significantly different expression between the both male sterile lines. Three Glutathione S-transferase (GSTs) encoded gene Os09g0467200, Os01g0369700, and Os01g0949800 were significantly up-regulated in Jiangcheng 3A, while not significantly different expression in 9311A. GSTs are ubiquitous and multifunctional enzymes in plant, and play a crucial role in plant defense though conjugation with glutathione, the attenuation of oxidative stress and the participation in hormone transport [48]. Notably, multiple GST genes were shown to be strongly inducible by the key defense hormone salicylic acid, which plays a key role in the activation of defence responses against biotrophic fungi [48]. Oxidoreductase and dehydrogenase as known to participate in generation of reactive oxygen species, which is one of several defence mechanisms used by plants against invading pathogens [49]. In our study, glucose-6-phosphate 1-dehydrogenase gene Os02g0600400 was up-regulated in both male sterile lines; however, the gene expression levels $\left(\log _{2}\right.$ FPKM) were higher in Jiangcheng $3 \mathrm{~A}$ than in $9311 \mathrm{~A}$ after $T$. horrida inoculation (Table 1 ). The roles of these genes in resistant $T$. horrida need to be further examined.

\section{DEGs involve in plant-pathogen interaction}

Page $11 / 27$ 
We identification 39 plant-pathogen interaction-related DEGs were exclusively present in resistance male sterile line Jiangcheng 3A. Among these, 10 DEGs were up-regulated and 29 DEGs were down-regulated after T. horrida inoculation (Fig. 4a); 10 up-regulation DEGs including OsWRKY24, OsWRKY53, OsPBL1, NB-ARC/LRR disease resistance protein gene Os04g0514600, OsCML14, OsCML7, OsJAZ8, hsp82B, SPK, and Osrboh9. Intracellular calcium transients participate in some biological processes associated with resistance, such as oxidative burst, PR gene expression, hypersensitive cell death, and systemic acquired resistance during plant-pathogen interactions $[50,51,52]$. In this study, OsCML7 and OsCML14 were upregulated in Jiangcheng $3 \mathrm{~A}$ kernels, we speculate that cellular calcium changes may participate in regulation pathway of $T$. horrida resistance, but the underlying mechanism should be further studied. Moreover, the highly conserved Heat shock proteins are involved in resistance to elevated temperatures and other environmental stresses [53], for example HSP90 interacts with a SA-induced protein kinase, which acts as a key component in signalling during plant defence [54]. Heat shock proteins hsp82B was induced in Jiangcheng $3 \mathrm{~A}$ after infection with $T$. horrida, showed that it may also play important roles in rice tolerance to T. horrida, but its functions should be further studied. Osrboh9 encoding respiratory burst oxidase homologue protein, and participate in generation of reactive oxygen species [55]; OsPBL1 encoding serine/threonine protein kinase, and play important role in SA-mediated defense [56]; these two genes were up-regulation at $8 \mathrm{~h}$ and $72 \mathrm{~h}$ in Jiangcheng $3 \mathrm{~A}$, respectively. This result showed that ROS may regulation $T$. horrida resistant at early stage and SA play a role at late stage. In addition, two WRKY transcription factor genes association with rice resistant OsWRKY24 and OsWRKY53 were up-regulation at $8 \mathrm{~h}$, their function are required for Jiangcheng $3 \mathrm{~A}^{\prime}$ ability to resistance T. horrida. For 29 down-regulation DEGs, several JAZ proteins encoding genes, such as Os04g0653000 and Os09g0401300 were downregulated at $8 \mathrm{~h}$. Jasmonic acid (JA) is an important plant hormone involved in regulation of plant defence, and JAZ proteins function as transcriptional repressors during in JA signaling [57]. Therefore, we speculate that these genes negatively regulate resistance to $T$. horrida.

\section{DEGs involved in plant hormone signal transduction}

Plant hormones are involved in many biological processes in enhanced resistance to environmental stresses, diseases and pathogen infections [58]. In the present study, many DEGs were related to plant hormone (including SA, JA, ET, and IAA) signal transduction. Several lines of evidence show that SA plays a key role in the activation of defence responses against biotrophic fungi [59]. Notably, the key gene OsNPR1 of SA-mediated defense pathway was up-regulation in both male sterile lines after T. horrida inoculation [60]; however, the gene expression level was higher in Jiangcheng 3A than in 9311A. TGA gene OsNIF1 could negatively regulates resistance to Xanthomonas oryzae pv. oryzae in rice [61]; in our result, this gene present down-regulation in both male sterile lines after $T$. horrida inoculation. We speculate that these 2 SA signal-related genes may play key roles in $T$. horrida resistance, but the specific functions of these genes should be further studied. ET and JA were also involved in resistance to pathogen infections [62]. In this study, several ET and JA signal-related genes were considered to be related to T. horrida resistance in rice. Some ethylene receptor, such as ETR2 were found to be involved in floral stage, overexpression of ETR2 in transgenic rice plants reduced ethylene sensitivity and delayed floral period [63]. ERS2 was up-regulated in Jiangcheng $3 A$ after T. horrida infected but were not significantly changed 
in 9311A. We speculate that ERS2 play a role in T. horrida resistant though influencing flowering. The jasmonyl-L-isoleucine synthase gene OsJAR2 was induced by T. horrida inoculation in both male sterile lines, the expression levels of OsJAR1 and OsJAR2 were induced in response to wounding and the expression of OsJAR1 was up-regulation after blast infection [64]. Jasmonatezim-domain (JAZ) proteins function as transcriptional repressors during in JA signaling, several JAZ proteins encoding genes, such as Os03g0180900 and Os10g0392400 were down-regulated in both male sterile lines.

Furthermore, ABA responsive element binding factor OsABF1 was a suppressor of floral stage, inhibit its expression in transgenic rice plants was delayed floral period [65]. In this study, OsABF1 was downregulation in Jiangcheng $3 \mathrm{~A}$ after $T$. horrida inoculation; however, not significantly changed in 9311A, so it may play an important role in T. horrida resistant though influencing flowering. Cytokinins (CTK) are plant hormones that play a key role in plant morphology, plant defence, leaf senescence and source-sink relationships [66]. OsRR1 was also involve in regulation of flowering time, OsRR1-overexpressing plants show a late-flowering phenotype [67]. In the present study, OsRR1 was up-regulation at $12 \mathrm{~h}$ in Jiangcheng $3 \mathrm{~A}$, but not significantly changed in $9311 \mathrm{~A}$. Therefore, we speculate that this gene may play similar roles as ERS2 and OsABF1, could hinder the T. horrida infection by delaying flowering.

\section{Transcriptional factors (TFs) identified from DEGs}

More than half of the 103 WRKY TF genes present in the rice genome are differentially expressed under biotic and abiotic stress conditions $[68,69]$. In our study, 34 WRKY genes showed altered expression in Jiangcheng $3 \mathrm{~A}$ kernels following T. horrida infection, of which 23 were up-regulated and 11 were downregulated at different time points. By contrast, 16 WRKY genes were showed altered expression in 9311A kernels following T. horrida infection, of which 10 were up-regulated and 6 were down-regulated (Additional file 13: Table S11). Out of the total DEGs WRKY genes detected, 13 were commonly regulated while 3 and 21 were exclusively regulated in 9311A and Jiangcheng 3A, respectively. Among 21 WRKY genes were unique to Jiangcheng $3 \mathrm{~A}$, OsWRKY12 and OsWRKY70 were up-regulated in Jiangcheng $3 \mathrm{~A}$ at $8 \mathrm{~h}$ post inoculation; suggesting that these gene play a positive role in resistance to T. horrida (Fig. 4c). Additionally, it has been shown that WRKY70 induces SA biosynthesis and inhibits JA biosynthesis. The expression level of WRKY70 is an indicator of the balance between SA and JA and determines which one of these hormones is more important [70]. OsWRKY12 is located upstream of OsNPR1 as a transcriptional activator in SA-dependent or JA-dependent defense signaling cascades [71]. OsWRKY10 was downregulation at 48 and $72 \mathrm{~h}$, and this gene was increased by JA treatment. These result showed that SA may play a more important role than JA in defence against $T$. horrida, Balbi and Devoto [72] showed that SA is more important than JA in defence against biotrophic fungi, which is consistent with our results. In addition, OsWRKY22, OsWRKY24, OsWRKY15, OsWRKY23, OsWRKY44, OsWRKY93, OsWRKY69, OsWRKY50, and OsWRKY35 were also up-regulation in Jiangcheng $3 \mathrm{~A}$ after $T$. horrida inoculation, but were not significantly changed in 9311A. The roles of these WRKY genes in resistant $T$. horrida need to be further identified.

MYB TFs are positive and negative regulators of pathogen resistance; for example, the Arabidopsis TF MYB30 promotes plant defence by positive regulation of HR [73]. In this study, we further found 60 MYB 
TF genes that were induced in Jiangcheng $3 \mathrm{~A}$ following T. horrida infection, of which 25 were upregulated, and 35 were down-regulated at different times points. In 9311A, 50 MYB TF genes showing differential expressed were identified after infection with T. horrida, of which 21 were up-regulated and 29 were down-regulated at different infection time points (Additional file 14: Table S12). Out of the total DEGs MYB genes detected, 36 were commonly regulated while 14 and 24 were exclusively regulated in 9311A and Jiangcheng 3A, respectively. Among 24 MYB genes were unique to Jiangcheng 3A (Fig. 4d), Osmyb4 was up-regulated in Jiangcheng $3 \mathrm{~A}$ at 8 and $12 \mathrm{~h}$ post inoculation, but were not significantly changed in 9311A after T. horrida inoculation. In Arabidopsis and cotton, overexpression Osmyb4 could increases biotic and abiotic stress tolerance [74]. We speculate that this gene play similar roles in T. horrida resistance regulation, but the specific functions of this gene under T. horrida inoculation in rice should be further studied. MYB genes Os05G0543600 and Os11G0207600 were also up-regulated in Jiangcheng 3A at $8 \mathrm{~h}, 0$ s04g0594100 at $24 \mathrm{~h}, 0 \mathrm{a08g} 0433400$ and Os11g0207600at $48 \mathrm{~h}$, and Os01g0127450, Os01g0228901, Os01g0274800, Os01g0977300, Os04g0533250, Os05g0459000, 0S06G0605750 at $72 \mathrm{~h}$ were up-regulated. Our results indicate that these MYB TFs may also play important roles in rice resistance to T. horrida; however, their functions should be further studied.

\section{Conclusions}

Transcriptome analysis showed that a resistant rice male sterile line exhibited more active responses to susceptible. DEGs in both male sterile lines were identified and enriched in many GO terms and pathways, suggesting that $T$. horrida resistance of rice is a complex mechanism. Glutathione metabolism-related genes, biosynthesis of unsaturated fatty acids-related genes, cutin, suberine and wax biosynthesis-related genes, flavonoid biosynthesis-related genes, plant hormone signal transduction-related genes, plantpathogen interaction-related genes, and many TFs were found to be involved in T. horrida resistant in rice. The findings reported herein increase our understanding of the molecular characteristics of rice resistant of $T$. horrida. The identified male sterile line Jiangcheng $3 \mathrm{~A}$ will be useful for inbreeding new rice varieties with a high $T$. horrida resistance.

\section{Abbreviations}

RKS: Rice kernel smut; qRT-PCR: Quantitative real time reverse transcription-polymerase chain reaction; STEM: Short Time-series Expression Miner software; Differential expression genes: DEGs; Gene Ontology: GO; Kyoto Encyclopedia of Genes and Genomes: KEGG; Transcriptional factors: TFs; Plant-pathogen interaction: PPI; Glutathione S-transferase: GSTs; Jasmonatezim-domain: JAZ; ethylene: ET; salicylic acid: SA; jasmonic acid: JA; abscisic acid: ABA; protein phosphatase 2C: PP2C; auxin: AUX; gibberellin: GA; cytokinin: CTK.

\section{Declarations}

Acknowledgments 
We thank Desuo Yin for assistance in obtaining plant materials.

\section{Authors' contributions}

AW completed the majority of the work for this article, including the experimental design, data analysis, and drafting of the manuscript. DY, XS, and WL provided useful suggestions. AW carried out bioinformatic analyses. PL and AZ revised the manuscript. All authors read and approved the final manuscript.

\section{Funding}

This work was supported by the Fuling Science and Technology project (2017ABB1029) and the Natural Science Foundation of China, Chongqing (cstc2018jcyjAX0594). The funding agent provided the financial support, the design of the experiment, and drafting of the manuscript.

\section{Availability of data and materials}

The data sets supporting the results of this article are available through the NCBIdatabase under the accession number: SRR8067633-SRR8067668.

\section{Ethics approval and consent to participate}

Not applicable.

\section{Consent for publication}

Not applicable.

\section{Competing interests}

The authors declare no conflict of interests.

\section{References}

1. Sharif MK, Butt MS, Anjum FM, Khan SH. Rice bran: a novel functional ingredient. Crit. Rev. Food Sci. Nutr. 2014; 54: 807-816.

2. Wu JG, Shi C, Zhang X. Estimating the amino acid composition in milled rice by near-infrared reflectance spectroscopy. Field Crop Research. 2002; 75: 1-7.

3. Chen Y, Yang X, Yao J, Kyaw EP, Zhang AF, Li YF, Gu CY, Zang HY, Gao TC. Simple and rapid detection of Tilletia horrida causing rice kernel smut in rice seeds. Sci. Rep. 2016; 6: 33258.

4. Webster RK, Gunnell PS. Compendium of rice diseases. Mycologia. 1992; 84: 953.

5. Takahashi Y. On Ustilago virens Cooke and a new species of Tilletia parasitic on rice plant. Tokyo Bot Mag. 1896; 10: 16-20.

6. Wang N, Ai P, Tang YF, Zhang J, Dai XJ, Li P, Zheng AP. Draft genome sequence of the rice kernel smut Tilletia horrida Strain QB-1. Genome Announc. 2015; 3, e00621-15. 
7. Biswas A. Kernel smut disease of rice: current status and future challenges. Environment and Ecology. 2003; 21, 336-351.

8. Tsuda M, Sasahara M, Ohara T, Kato S. Optimal application timing of simeconazole granules for control of rice kernel smut and false smut. Journal of General Plant Pathology. 2006; 72: 301-304.

9. Rogerson CT. Illustrated genera of smut fungi. Brittonia. 1988; 40: 107.

10. Shyama Sundari DC, Boon HC, Kalaivani N. In silico analysis of disease resistance and defencerelated genes for a major sheath blight qShb 9-2 QTL in rice. Malaysian Journal of Microbiology. 2018; 14:534-546.

11. Zhang $\mathrm{H}$, Wang S. Rice versus Xanthomonas oryzae pv. oryzae: a unique pathosystem. Current Opinion in Plant Biology. 2013; 16:188-195.

12. Hittalmani S, Parco A, Mew TV, Zeigler RS, Huang N. Fine mapping and DNA markerassisted pyramiding of the three major genes for blast resistance in rice. Theoretical and Applied Genetics. 2000; 100:1121-1128.

13. Jeung JU, Kim BR, Cho YC, Han SS, Moon HP, Lee YT, Jena KK. A novel gene, Pi40(t), linked to the DNA markers derived from NBS-LRR motifs confers broad spectrum of blast resistance in rice. Theoretical and Applied Genetics. 2007; 115:1163-1177.

14. Wang AJ, Pang LY, Wang N, Ai P, Yin DS, Li SC, Deng QM, Zhu J, Liang YY, Zhu JQ, Li P, Zheng AP. The pathogenic mechanisms of Tilletia horrida as revealed by comparative and functional genomics. Scientific reports 2018a; 8:15413.

15. Wang AJ, Yin DS, Fu R, Pan LX, Gu SS, Jiang B, Zheng AP. Evaluation of resistance to rice kernel smut in seventy-eight species of rice sterile line. Acta phytopathol. sin. 2018b; 48(2): 207-212.

16. Lai Z, Mengiste T. Genetic and cellular mechanisms regulating plant responses to necrotrophic pathogens. Curr. Opin. Plant Biol. 2013;16: 505-512.

17. Marioni JC, Mason CE, Mane SM, Stephens M, Gilad Y. RNA-seq: An assessment of technical reproducibility and comparison with gene expression arrays. Genome Res. 2008; 18: 1509-1517.

18. Bagnaresi P, Biselli C, Qrru L, Urso S, Crispino L, Abbruscato P, Piffanelli P, Lupotto E, Cattivelli L, Valè G. Comparative transcriptome profiling of the early response to Magnaporthe oryzae in durable resistant vs susceptible rice (Oryza sativa L.) genotypes. PLoS One. 2012; 7: e51609.

19. Skibbe DS, Doehlemann G, Fernandes J, Walbot V. Maize tumors caused by Ustilago maydis require organ-specific genes in host and pathogen. Science. 2010; 328: 89-92.

20. Ditt RF, Kerr KF, De FP, Delrow J, Comai L, Nester EW. The Arabidopsis thaliana transcriptome in response to Agrobacterium tumefaciens. Mol. Plant Microbe Interact. 2006; 19: 665-681.

21. Yang LR, Xie LH, Xue BQ, Goodwin PH, Quan X, Zheng C, Liu T, Lei Z, Yang X, Chao Y, Wu C. Comparative transcriptome profiling of the early infection of wheat roots by Gaeumannomyces graminis var. tritici. PLoS One. 2015; 10, e0120691.

22. Zhang JF, Chen L, Fu CL, Wang LX, Liu HN, Cheng YZ, Li SC, Deng QM, Wang SQ, Zhu J, Liang YY, Li P, Zheng AP. Comparative transcriptome analyses of gene expression changes triggered by Rhizoctonia solani AG1 IA infectionin resistant and susceptible rice varieties. Front. Plant Sci. 2017; 8: 1422. 483 
23. Sangram KL, Amit K, Viswanathan C, Kailash CB. Comparative analysis of drought-responsive transcriptome in Indica rice genotypes with contrasting drought tolerance. Plant Biotechnology Journal.2011; 9, pp. 315-327.

24. Thatcher LF, Williams AH, Garg GG. Buck SA, Singh KB. Transcriptome analysis of the fungal pathogen Fusarium oxysporum f. sp. medicaginis during colonisation of resistant and susceptible Medicago truncatula hosts identifies differential pathogenicity profiles and novel candidate effectors. BMC genomics. 2016; 17: 860 .

25. Langmead B, Trapnell C, Pop M, Salzberg SL. Ultrafast and memory-efficient alignment of short DNA sequences to the human genome. Genome Biol. 2009; 10(3), R25.

26. Kim D, Pertea G, Trapnell C, Pimentel H, Kelley R, Salzberg SL. TopHat 2: accurate alignment of transcriptomes in the presence of insertions, deletions and gene fusions. Genome Biol. 2013; 14(4): R36.

27. Trapnell C, Williams BA, Pertea G, Mortazavi A, Kwan G, van Baren MJ, Salzberg SL, Wold BJ, Pachter L. Transcript assembly and quantification by RNA-Seq reveals unannotated transcripts and isoform switching during cell differentiation. Nat. Biotechnol. 2010; 28: 511-515.

28. Anders S, Huber W. Differential expression analysis for sequence count data. Genome Biol. 2010; 11: R106.

29. Anders S, Huber W. Differential expression of RNA-Seq data at the gene level-the DESeq package. EMBL, Heidelberg, Germany. 2012.

30. Benjamini Y, Hochberg Y. Controlling the false discovery rate: a practical and powerful approach to multiple testing. Journal of the Royal Statistical Society. Series B (Methodological). 1995; 57(1): 289300.

31. Ernst J, Bar-Joseph Z. STEM: a tool for the analysis of short time series gene expression data. BMC bioinformatics. 2006; 7: 191.

32. Wang L, Feng Z, Wang $X$, Zhang X. DEGseq: an R package for identifying differentially expressed genes from RNA-seq data. Bioinformatics. 2010; 26: 136-138.

33. Young MD, Wakefield MJ, Smyth GK, Oshlack A. Gene ontology analysis for RNA-seq: accounting for selection bias. Genome Biol. 2010; 11: R14.

34. Mao X, Cai T, Olyarchuk JG, Wei L. Automated genome annotation and pathway identification using the KEGG Orthology (KO) as a controlled vocabulary. Bioinformatics. 2005; 21: 3787-93.

35. Kanehisa M, Araki M, Gota S, Hattori M, Hirakawa M, Itoh M, Katayama T, Kawashima S, Okuda S, Tokimatsu T, Yamanishi Y. KEGG for linking genomes to life and the environment. Nucleic Acids Res. 36(Database issue): 2008; D480-4.

36. Michelotti V, Lamontanara A, Buriani G, Orrù L, Cellini A, Donati I, Vanneste GL, Cattivelli L, Tacconi G, Spinelli F. Comparative transcriptome analysis of the interaction between Actinidia chinensis var. chinensis and Pseudomonas syringae pv. actinidiae in absence and presence of acibenzolar-Smethyl. BMC Genomics. 2018; 19:585. 
37. Wu XX, Gong QH, Ni XP, Zhou Y, Gao ZH. UFGT: The Key Enzyme Associated with the Petals Variegation in Japanese Apricot. Front. Plant Sci. 2017; 8:108.

38. Jones JD, Dangl JL. The plant immune system. Nature. 2006; 444: 323-329.

39. Bonardi V, Dangl JL. How complex are intracellular immune receptor signaling complexes? Front Plant Sci 2016; 3:237.

40. Pieterse CMJ, Leon-Reyes A, van der Ent S, Van Wees SCM. Networking by small-molecules hormones in plant immunity. Nat. Chem. Biol. 2009; 5: 308-316.

41. Seo E, Choi D. Functional studies of transcription factors involved in plant defenses in the genomics era. Brief. Func. Genomics. 2015; 14: 260.

42. Pradhan SK, Pandit E, Nayak DK, Behera L, Mohapatra T. Genes, pathways and transcription factors involved in seedling stage chilling stress tolerance in indica rice through RNA-Seq analysis. BMC Plant Biology, 2019; 19:352.

43. Koskimaki JJ, Hokkanen J, Jaakola L, Suorsa M, Tolonen A, Mattila S, Pirttila AM. Flavonoid biosynthesis and degradation play a role in early defence responses of bilberry (vaccinium myrtillus) against biotic stress. Eur J Plant Pathol. 2009; 125:629-640.

44. Liu X, Zhang S, Whitworth RJ, Stuart JJ, Chen MS. Unbalanced activation of glutathione metabolic pathways suggests potential involvement in plant defense against the gall midge mayetiola destructor in wheat. Scientific Reports.2015; 5:8092.

45. Boerjan W, Ralph J, Baucher M. Lignin biosynthesis. Annu. Rev. Plant Biol. 2003; 54: 519-546.

46. Kersten B, Ghirardo A, Schnitzler JP, Kanawati B, Schmitt-Kopplin P, Fladung M, Schroeder H. Integrated transcriptomics and metabolomics decipher differences in the resistance of pedunculate oak to the herbivore Tortrix viridana L. BMC genomics. 2013; 14:737.

47. Schreiber L. Transport barriers made of cutin, suberin and associated waxes. Trends Plant Sci. 2010; 15: 546-553.

48. Gullner G, Komives T, Kiraly L, Schroder P. Glutathione S-Transferase Enzymes in Plant-Pathogen Interactions. Front. Plant Sci. 2018; 9:1836.

49. Suzuki N, Miller G, Morales J, Shulaev V, Torres MA, Mittler R. Respiratory burst oxidases: the engines of ROS signaling. Curr Opin Plant Biol. 2011; 14 (6):691-9.

50. Du LQ, Ali GS, Simons KA, Hou JG, Yang TB, Reddy ASN, Poovaiah BW. Ca ${ }^{2+}$ /calmodulin regulates salicylic-acid-mediated plant immunity. Nature.2009; 457: 1154-1158.

51. Ogasawara Y, Kaya H, Hiraoka G, Yumoto F, Kimura S, Kadota Y, Hishinuma H, Senzaki E, Yamagoe S, Nagata K, Nara M, Suzuki K, Tanokura M, Kuchitsu K. Synergistic activation of the Arabidopsis NADPH oxidase AtrbohD by $\mathrm{Ca}^{2+}$ and phosphorylation. J. Biol. Chem. 2008; 283: 8885-8892.

52. Torres MA, Dangl JL. Reactive oxygen species signaling in response to pathogens. Plant Physiol. 2006; 141: 373-378.

53. Kilic A, Mandal K. Heat shock proteins: pathogenic role in atherosclerosis and potential therapeutic implications. Autoimmune Diseases. 2015; 2012(5100): 502813. 
54. Grammatikakis N, Vultur A, Ramana CV, Siganou A, Schweinfest CW, Watson DK, Raptis L. The role of Hsp90N, a new member of the Hsp90 family, in signal transduction and neoplastic transformation. J Biol Chem. 2002; 277(10): 8312-20.

55. Liu J, Zhou J, Xing D. Phosphatidylinositol 3-Kinase Plays a Vital Role in Regulation of Rice Seed Vigor via Altering NADPH Oxidase Activity. PLoS ONE. 2012; 7(3): e33817.

56. Lee KJ, Kin K. The rice serine/threonine protein kinase OsPBL1 (ORYZA SATIVA ARABIDOPSIS PBS1 LIKE 1) is potentially involved in resistance to rice stripe disease. Plant Growth Regulation. 2015; 77(1): 67-75.

57. Cai Q, Yuan Z, Chen MJ, Yin CS, Luo ZJ, Zhao XX, Liang WQ, Hu JP, Zhang DB. Jasmonic acid regulates spikelet development in rice. Nature Communications. 2014; 5: 3476.

58. Bari R, Jones JD. Role of plant hormones in plant defence responses. Plant Molecular Biology. 2009; 69(4):473-88.

59. Glazebrook J. Contrasting mechanisms of defense against biotrophic and necrotrophic pathogens. Annu Rev Phytopathol. 2005; 43:205-227.

60. Yuan YX, Zhong SH, Li Q, Zhu ZR, Lou YG, Wang LY, Wang JJ, Wang MY, Li QL, Yang DL, He ZH. Functional analysis of rice NPR1-like genes reveals that OsNPR1/NH1 is the rice orthologue conferring disease resistance with enhanced herbivore susceptibility. Plant Biotechnology Journal. 2007; 5(2): 313-324.

61. Fitzgerald HA, Canlas PE, Chern MS, Ronald PC. Alteration of TGA factor activity in rice results in enhanced tolerance to Xanthomonas oryzae pv. oryzae. The Plant Journal. 2005; 43(3): 335-347.

62. Arena GD, Ramos-Gonzalez PL, Nunes MA, Ribeiro-Alves M, Camargo LEA, Kitajima EW, Machado MA, Freitas-Astua J. Citrus leprosis virus C Infection Results in Hypersensitive-Like Response, Suppression of the JA/ET Plant Defense Pathway and Promotion of the Colonization of Its Mite Vector. Front Plant Sci. 2016; 7:1757.

63. Wuriyanghan H, Zhang B, Cao WH, Ma B, Lei G, Liu YF, Wei W, Wu HJ, Chen LJ, Chen HW, Cao YR, He SJ, Zhang WK, Wang XJ, Chen SY, Zhang JS. The Ethylene Receptor ETR2 Delays Floral Transition and Affects Starch Accumulation in Rice. The Plant Cell. 2009; 21(5): 1473-1494.

64. Wakuta S, Suzuki E, Saburi W, Matsuura H, Nabeta K, Imai R, Matsui H. OsJAR1 and OsJAR2 are jasmonyl---isoleucine synthases involved in wound- and pathogen-induced jasmonic acid signaling. Biochemical and Biophysical Research Communications. 2011; 409(4): 634-639.

65. Zhang CY, Liu J, Zhao T, Gomez A, Li C, Yu CS, Li HY, Lin JZ, Yang YZ, Liu B, Lin CT. A DroughtInducible Transcription Factor Delays Reproductive Timing in Rice. Plant Physiology. 2016; 171(1): 334-343.

66. Pasternak O, Sikorski MM. Cytokinins in plant defense mechanisms. Biotechnologia. 2002; 3:153-161.

67. Cho LH, Yoon J, Pasriga R, An G. Homodimerization of Ehd1 Is Required to Induce Flowering in Rice. Plant Physiology. 2016;170(4): 2159-2171.

68. Ramamoorthy R, Jiang SY, Kumar N, Venkatesh PN, Ramachandran S. A comprehensive transcriptional profiling of the WRKY gene family in rice under various abiotic and phytohormone 
treatments. Plant Cell Physiol. 2008; 49: 865-879.

69. Berri S, Abbruscato P, Faivre-Rampant O, Brasileiro AV, Fumasoni I, Satoh K, Kikuchi S, Mizzi L, Morandini P, Enrico Pè M, Piffanelli P. Characterization of WRKY co-regulatory networks in rice and Arabidopsis. BMC Plant Biol.2003; 9: 120-132.

70. Zhang LY, Gu LK, Ringler P, Smith S, Rushton PJ, Shen QX. Three WRKY transcription factors additively repress abscisic acid and gibberellin signaling in aleurone cells. Plant Science. 2015; 236 : $214-222$.

71. Liu XQ, Bai XQ, Qian Q, Wang XJ, Chen MS, Chu CC. OsWRKY03, a rice transcriptional activator that functions in defense signaling pathway upstream of OsNPR1. Cell Research. 2005; 15(8): 593-603.

72. Balbi V, Devoto A. Jasmonate signalling network in Arabidopsis thaliana: crucial regulatory nodes and new physiological scenarios. New Phytol. 2008; 177: 301-318.

73. Marino D, Froidure S, Canonne J, Ben K S, Khafif M. Arabidopsis ubiquitin ligase MIEL1 mediates degradation of the transcription factor MYB30 weakening plant defence. Nat Commun. 2013; 4:1476.

74. Vannini C, Campa M, Iriti M, Genga A, Faoro F, Carravieri S, Rotino GL, Rossoni M, Spinardi A, Bracale M. Evaluation of transgenic tomato plants ectopically expressing the rice Osmyb4 gene. Plant Science. 2007; 173(2): 231-239.

\section{Tables}

Table 1 Key pathway-related genes that were differentially expressed during T. horrida inoculation in Jiangcheng $3 \mathrm{~A}$. 


\begin{tabular}{|c|c|c|c|c|c|c|c|}
\hline \multirow[t]{2}{*}{ Pathway } & \multirow[t]{2}{*}{ Gene ID } & \multicolumn{5}{|c|}{ Fold change } & \multirow[t]{2}{*}{ Annotation } \\
\hline & & K8/G8 & $\mathrm{K} 12 / \mathrm{G} 12$ & K24/G24 & K48/G48 & K72/G72 & \\
\hline \multirow{7}{*}{$\begin{array}{c}\text { cutin, } \\
\text { suberine } \\
\text { and wax } \\
\text { biosynthesis }\end{array}$} & Os09g0363900 & $1.58 /-$ & $-1-$ & $-1-$ & $-1-$ & $-1-$ & ONI3 \\
\hline & Os03g0167600 & $3.25 /-$ & $-1-$ & $-1-$ & $-1-$ & $-1-$ & DPW \\
\hline & Os03g0222600 & $-1-$ & $-1-$ & $-1-$ & $-1-$ & $5.93 / 5.24$ & $\begin{array}{c}\text { caleosin related } \\
\text { protein }\end{array}$ \\
\hline & Os04g0510900 & $-1-$ & $-1-$ & $-1-$ & $-1-$ & $6.06 /-$ & $\begin{array}{c}\text { caleosin related } \\
\text { protein }\end{array}$ \\
\hline & Os10g0486100 & $-1-$ & $-1-$ & $-1-$ & $-1-$ & $4.64 /-$ & cytochrome P450 \\
\hline & Os02g0621300 & $-1-$ & $-1-$ & $-1-$ & $-1-$ & $1.34 /-$ & OsGL1-4 \\
\hline & Os04g0560100 & $-1-$ & $-1-$ & $-1-$ & $-1-$ & $3.47 /-$ & cytochrome P450 \\
\hline \multirow[t]{6}{*}{$\begin{array}{c}\text { Flavonoid } \\
\text { biosynthesis }\end{array}$} & Os04g0630800 & $2.23 /-$ & $2.46 / 1.51$ & $-1-$ & $-1-$ & $-1-$ & $\begin{array}{l}\text { leucoanthocyanidin } \\
\text { reductase }\end{array}$ \\
\hline & Os10g0317900 & $-2.74 /-$ & $-2.25 /-$ & $-1-$ & $-1-$ & $-2.08 /-$ & cytochrome P450 \\
\hline & Os09g0481400 & $1.62 /-$ & $1.83 /-$ & $1.60 /-$ & $2.54 /-$ & $-1-$ & $\begin{array}{c}\text { caffeoyl-CoA O- } \\
\text { methyltransferase }\end{array}$ \\
\hline & Os04g0500700 & $-1.74 /-$ & $-1-$ & $-1-$ & $-1-$ & $-1-$ & $\begin{array}{c}\text { transferase family } \\
\text { protein }\end{array}$ \\
\hline & Os08g0498100 & $-1-$ & $-1-$ & $1.63 / 1.16$ & $-1-$ & $-1-$ & $\begin{array}{c}\text { caffeoyl-CoA O- } \\
\text { methyltransferase }\end{array}$ \\
\hline & Os02g0467600 & $-1-$ & $-1-$ & $-1-$ & $-1-$ & $3.21 /-$ & cytochrome P450 \\
\hline \multirow{6}{*}{$\begin{array}{l}\text { biosynthesis } \\
\text { of } \\
\text { unsaturated } \\
\text { fatty acids }\end{array}$} & Os08g0200100 & $2.26 /-$ & $1.65 /-$ & $-1-$ & $-1-$ & $-1-$ & acyl-desaturase \\
\hline & Os07g0417200 & $5.86 /-$ & $-1-$ & $-1-$ & $7.30 / 3.97$ & $4.97 /-$ & OsFAD2-2 \\
\hline & Os07g0416900 & $6.77 /-$ & $7.52 /-$ & $-1-$ & $6.69 /-$ & $5.09 /-$ & OsFAD2-3 \\
\hline & Os07g0693800 & $2.19 /-$ & $-/ 3.23$ & $-1-$ & $-1-$ & $-1-$ & OsFAD8 \\
\hline & Os01g0880800 & $-1-$ & $-1-$ & $-1-$ & $-1-$ & $44.25 / 46.21$ & acyl-desaturase \\
\hline & Os03g0748100 & $1.94 /-$ & $4.92 /-$ & $-1-$ & $-1-$ & $-1-$ & oxidoreductase \\
\hline \multirow{4}{*}{$\begin{array}{l}\text { tyrosine } \\
\text { metabolism }\end{array}$} & Os07g0621800 & $1.55 /-$ & $1.46 /-$ & $1.84 /-$ & $2.53 / 1.79$ & $-1-$ & dehydrogenase \\
\hline & Os02g0306401 & $-1-$ & $-1-$ & $1.76 /-$ & $-1-$ & $3.27 /-$ & OsNAAT1 \\
\hline & Os01g0770200 & $-1-$ & $-1-$ & $2.09 /-$ & $-1-$ & $-1-$ & TYDC \\
\hline & Os11g0210600 & $-1-$ & $-1-$ & $1.32 /-$ & $-1-$ & $-1-$ & dehydrogenase \\
\hline \multirow[t]{10}{*}{$\begin{array}{l}\text { glutathione } \\
\text { metabolism }\end{array}$} & Os02g0237100 & $2.08 /-$ & $-/ 2.94$ & $-/ 3.73$ & $-1-$ & $-1-$ & $\begin{array}{l}\text { spermidine } \\
\text { synthase }\end{array}$ \\
\hline & Os06g0127900 & $2.42 /-$ & $2.56 / 2.18$ & $-1-$ & $-1-$ & $2.98 / 1.75$ & RNRS2 \\
\hline & Os01g0949800 & $-1-$ & $-1-$ & $3.37 /-$ & $-1-$ & $-1-$ & $\begin{array}{l}\text { glutathione S- } \\
\text { transferase }\end{array}$ \\
\hline & Os09g0467200 & $1.88 /-$ & $3.85 /-$ & $3.60 / 2.22$ & $4.51 /-$ & $-/ 3.28$ & $\begin{array}{c}\text { glutathione S- } \\
\text { transferase }\end{array}$ \\
\hline & Os10g0415300 & $2.26 /-$ & $-1-$ & $-1-$ & $-1-$ & $2.78 /-$ & OsGR3 \\
\hline & Os06g0168600 & $1.96 /-$ & $-/ 1.11$ & $-1-$ & $-1-$ & $1.72 /-$ & RNRL1 \\
\hline & Os01g0369700 & $-1-$ & $1.62 /-$ & $-1-$ & $-1-$ & $-1-$ & $\begin{array}{l}\text { glutathione S- } \\
\text { transferase }\end{array}$ \\
\hline & Os02g0600400 & $-1-$ & $2.80 / 1.87$ & $-1-$ & $-1-$ & $-1-$ & $\begin{array}{c}\text { glucose-6- } \\
\text { phosphate 1- } \\
\text { dehydrogenase }\end{array}$ \\
\hline & Os04g0508200 & $-1-$ & $-1-$ & $-1-$ & $-1-$ & $2.02 / 1.55$ & dehydrogenase \\
\hline & Os09g0538600 & $-1-$ & $-1-$ & $-1-$ & $-1-$ & $3.74 / 1.66$ & $\begin{array}{c}\text { L-ascorbate } \\
\text { peroxidase } 4 \\
\end{array}$ \\
\hline
\end{tabular}

Noted: “-” means no present different expression at different inoculation times point. 


\section{Figures}

a

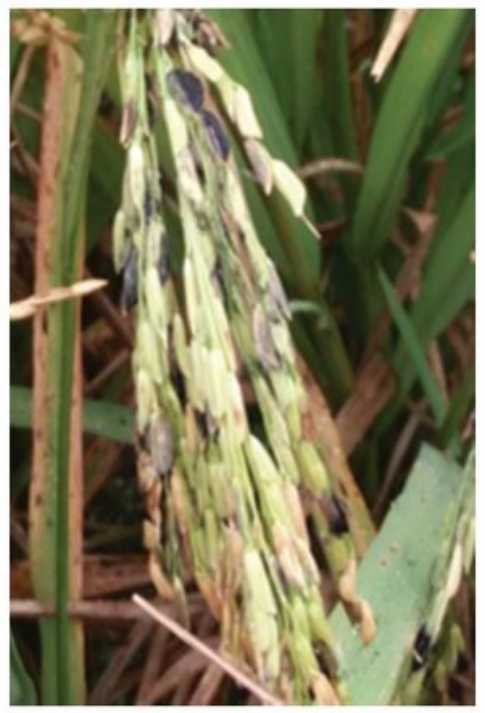

d

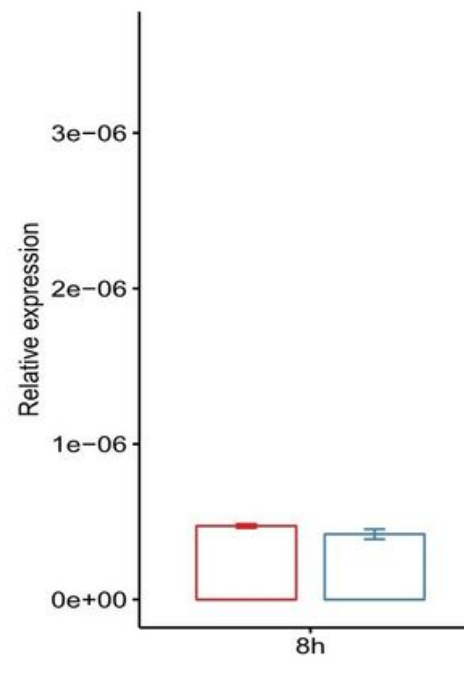

b

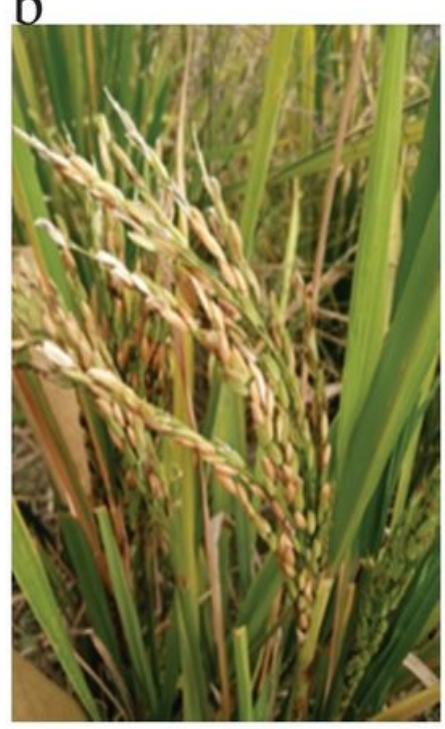

$\mathrm{C}$

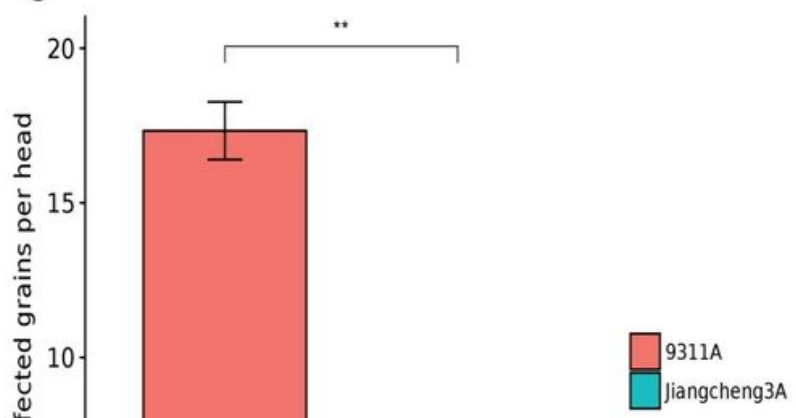

\section{Figure 1}

Symptoms of T. horrida infection on resistant (Jiangcheng 3A) and susceptible (9311A) rice male sterile lines. a, b Disease symptoms at 31 days post inoculation; $c$ Average number of infected grains per panicle at 31 days post inoculation ( $n=20)$; $d$ Analysis of the relative abundance of T. horrida fungus using qRTPCR. The $18 \mathrm{~S}$ rRNA sequence of T. horrida was amplified from samples harvested at $8,12,24,48$, and $72 \mathrm{~h}$ post inoculation. 
a

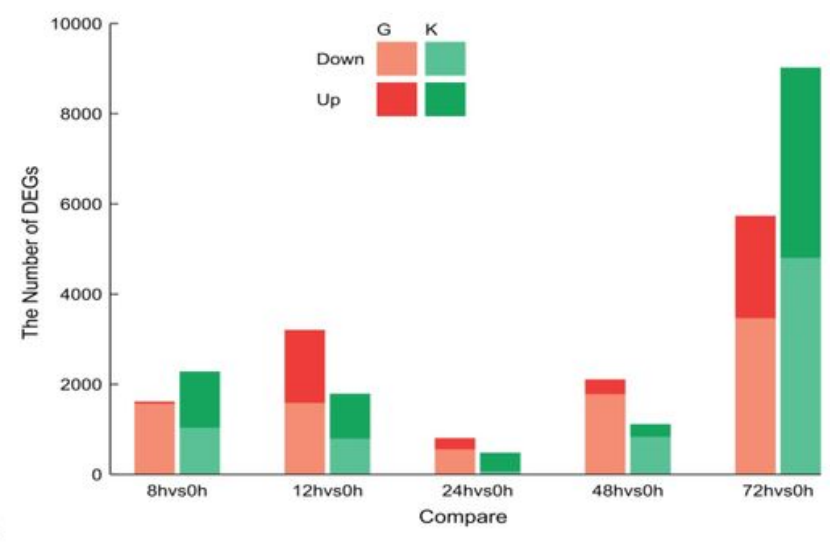

$\mathrm{c}$

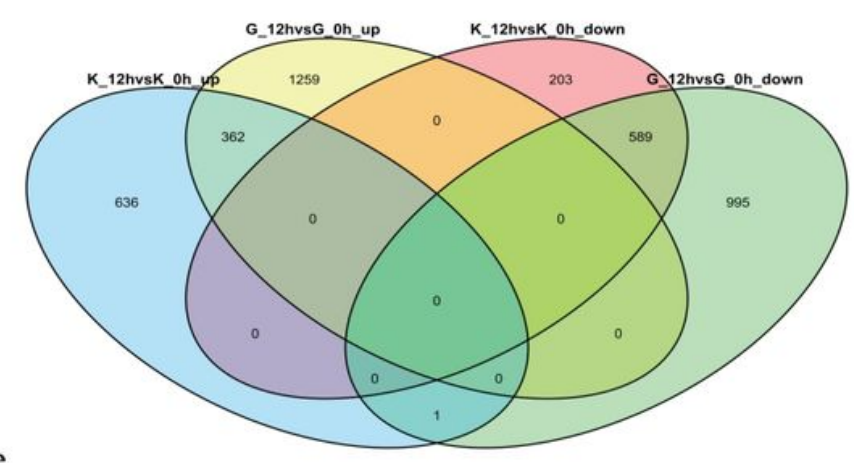

e

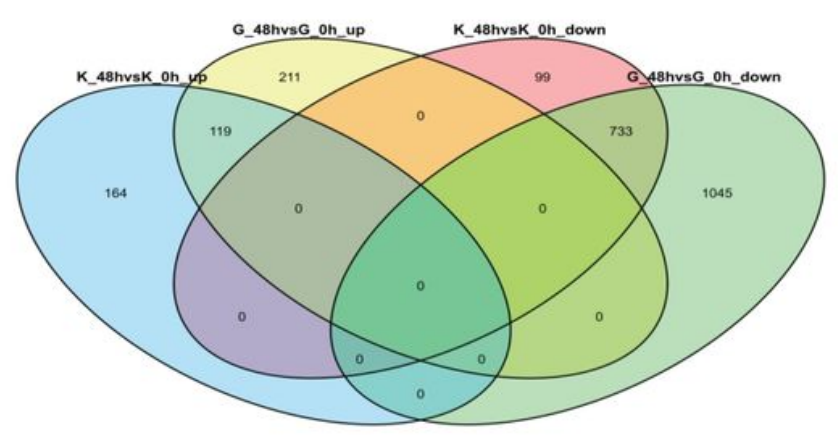

b

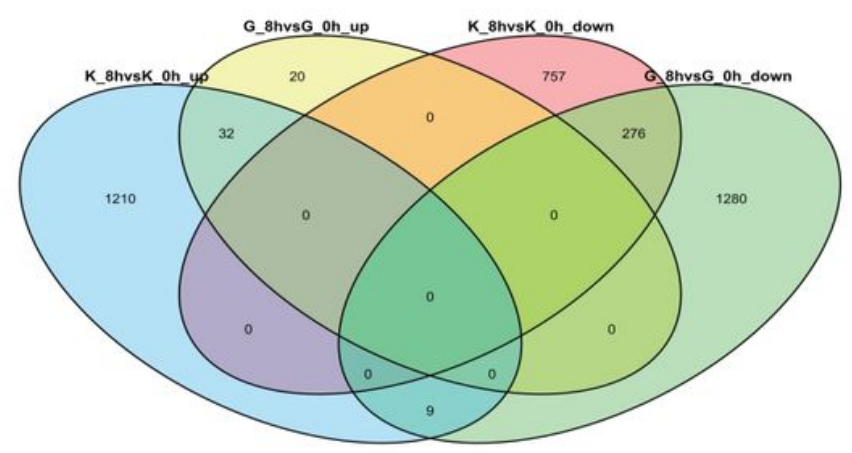

d
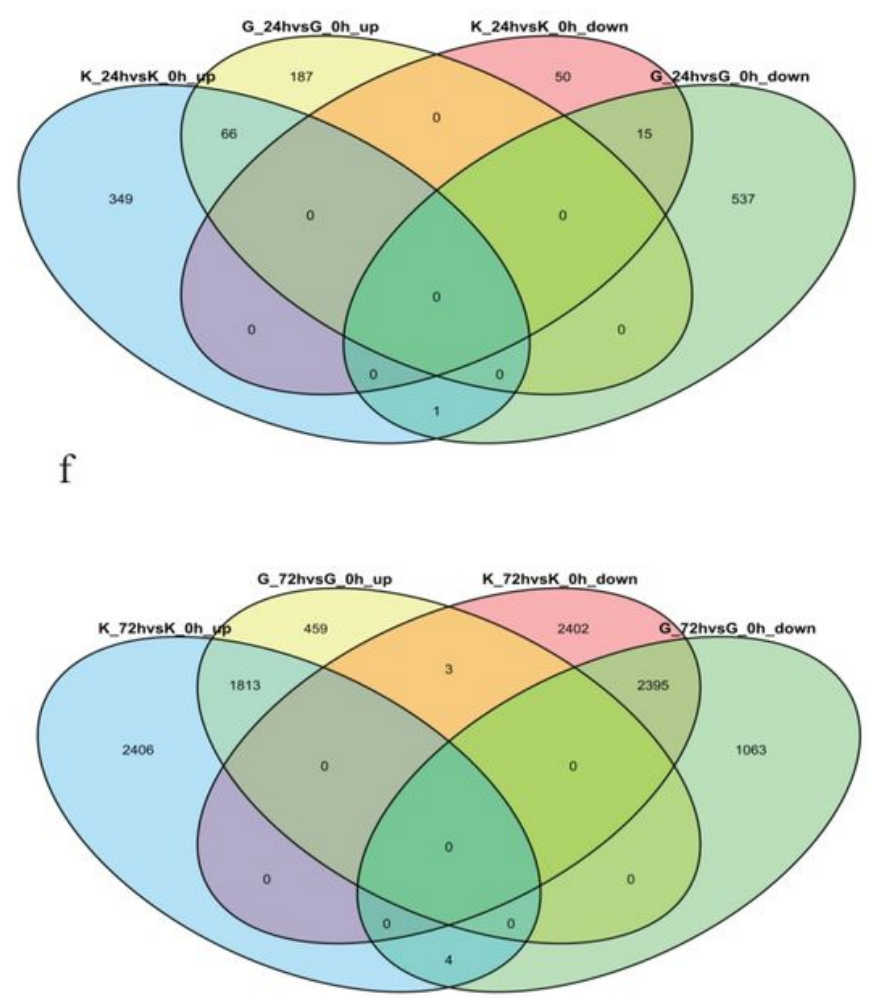

\section{Figure 2}

Different expression genes (DEGs) in Jiangcheng $3 \mathrm{~A}$ and 9311A after T. horrida inoculation. a Number of up-regulation and down-regulation DEGs in Jiangcheng $3 \mathrm{~A}$ and $9311 \mathrm{~A}$ after T. horrida inoculation; $\mathrm{b}$ Venn diagrams showing the overlapping of the DEGs number in response to T. horrida infection at $8 \mathrm{~h}$ in Jiangcheng $3 \mathrm{~A}$ and $9311 \mathrm{~A} ; \mathrm{C}$ Venn diagrams showing the overlapping of the DEGs number in response to T. horrida infection at $12 \mathrm{~h}$ in Jiangcheng $3 \mathrm{~A}$ and $9311 \mathrm{~A} ; \mathrm{d}$ Venn diagrams showing the overlapping of the DEGs number in response to T. horrida infection at $24 \mathrm{~h}$ in Jiangcheng $3 \mathrm{~A}$ and $9311 \mathrm{~A}$; e Venn diagrams showing the overlapping of the DEGs number in response to T. horrida infection at $48 \mathrm{~h}$ in Jiangcheng $3 \mathrm{~A}$ and $9311 \mathrm{~A} ; \mathrm{f}$ Venn diagrams showing the overlapping of the DEGs number in response to T. horrida infection at $72 \mathrm{~h}$ in Jiangcheng $3 \mathrm{~A}$ and $9311 \mathrm{~A}$. 
a

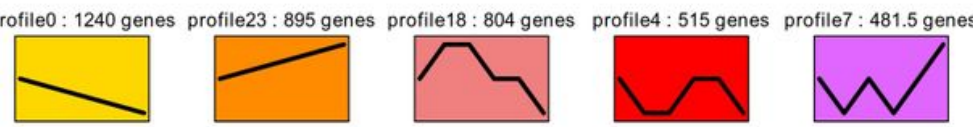

(n)
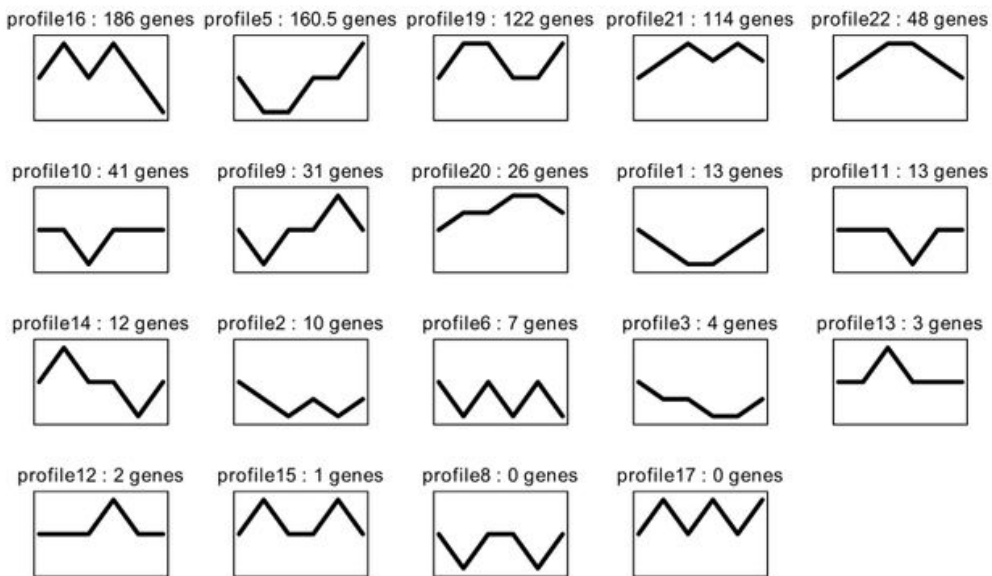

$\mathrm{C}$
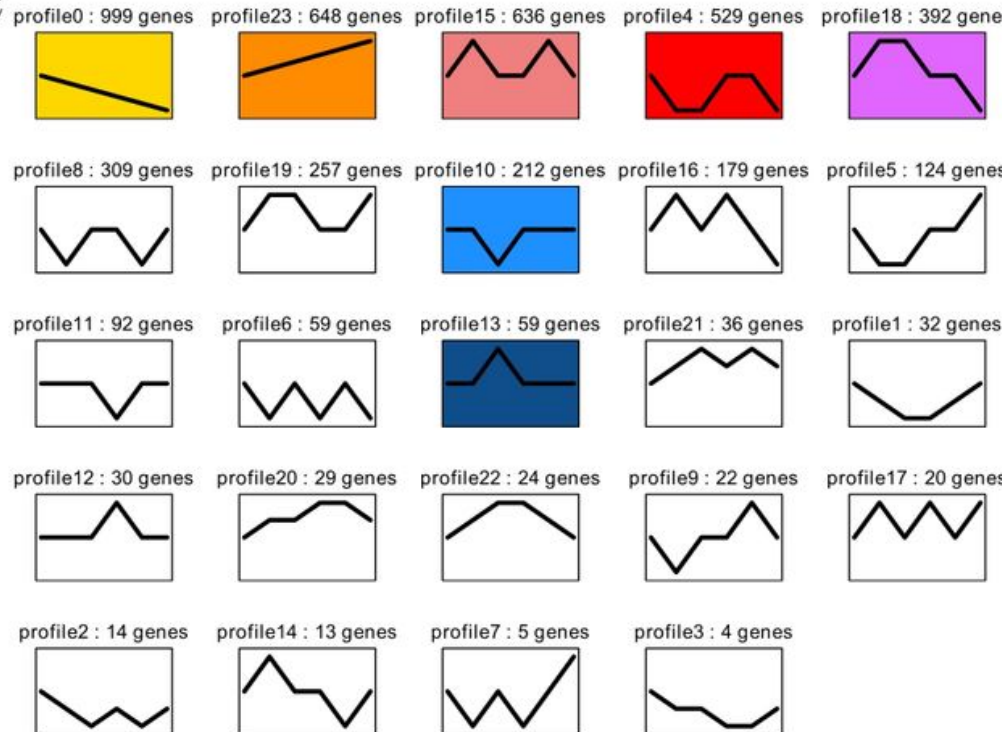

b
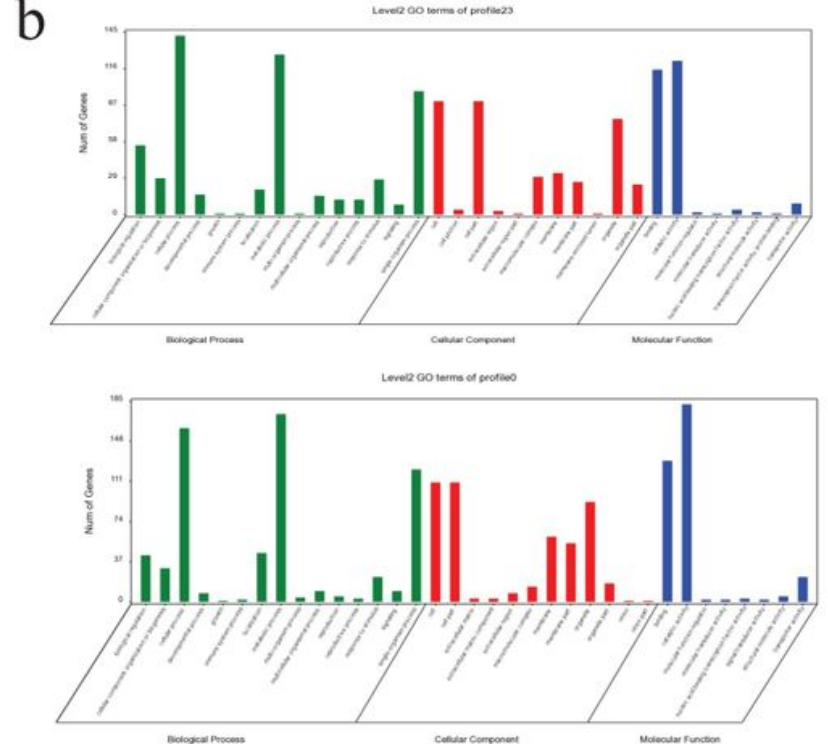

d
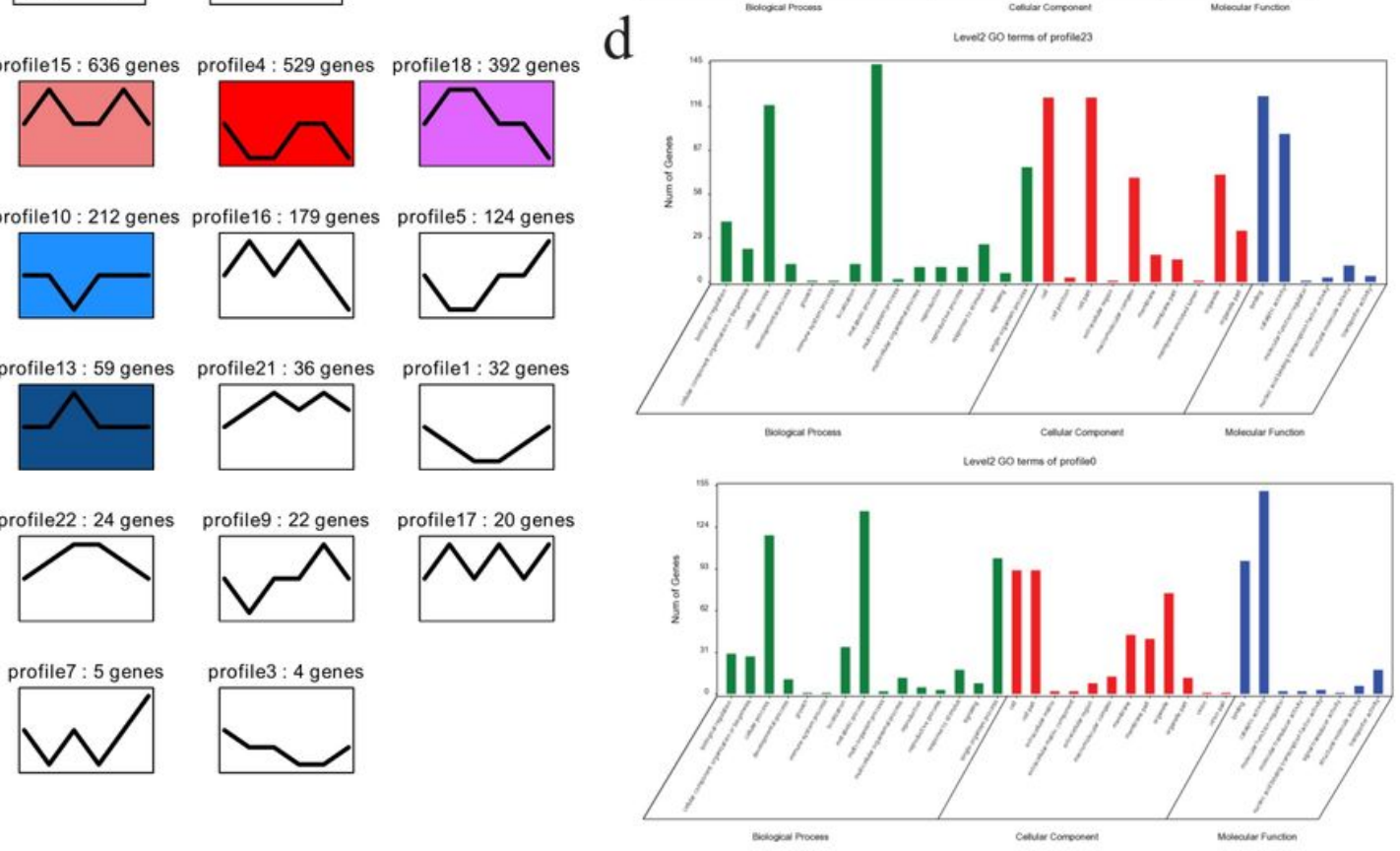

\section{Figure 3}

The clustering analysis and functional classification for 4,729 DEGs identified in both genotypes infected with T. horrida over a time period of $72 \mathrm{~h}$. a Clustering analysis of 4,729 DEGs in Jiangcheng $3 \mathrm{~A} ; \mathrm{b}$ GO enrichment analysis of profile 23 and profile 0 in Jiangcheng 3A; c Clustering analysis of 4,729 DEGs in $9311 \mathrm{~A} ; \mathrm{d}$ GO enrichment analysis of profile 23 and profile 0 in 9311A. GO terms were enriched using a hypergeometric test, and q-values were adjusted with FDR $<0.05$. 
a

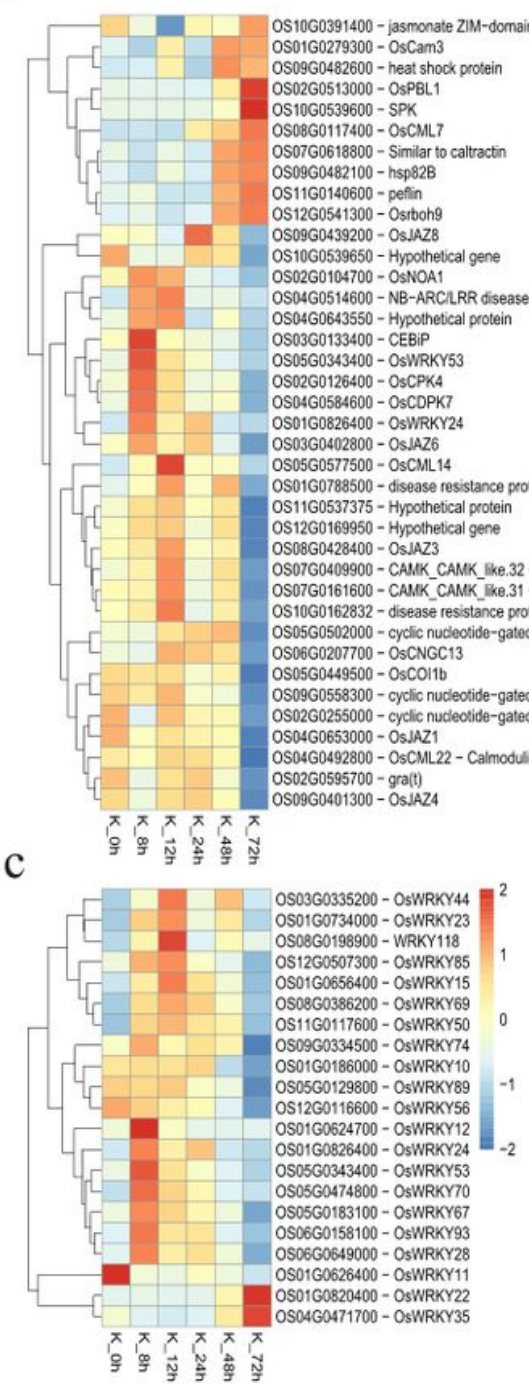

b

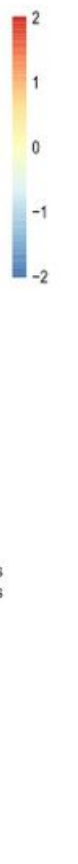

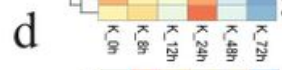

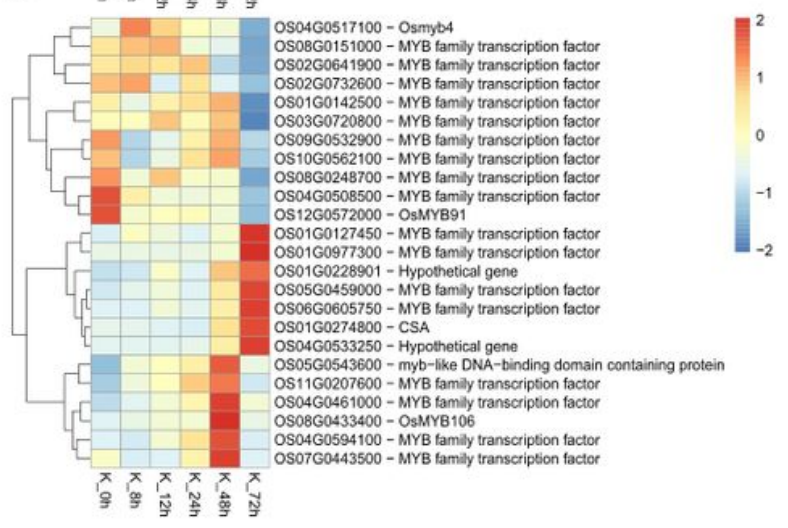

Figure 4

Expression analysis of genes in Jiangcheng $3 \mathrm{~A}$ and 9311A infected with T. horrida. a Heatmap of 39 plant-pathogen interaction genes unique to Jiangcheng 3A kernels; b Heatmap of 39 plant hormone signal transduction genes unique to Jiangcheng $3 A$ kernels; $c$ Heatmap of 21 WRKY TF genes unique to Jiangcheng 3A kernels; d Heatmap of 24 MYB TF genes unique to Jiangcheng $3 A$ kernels.
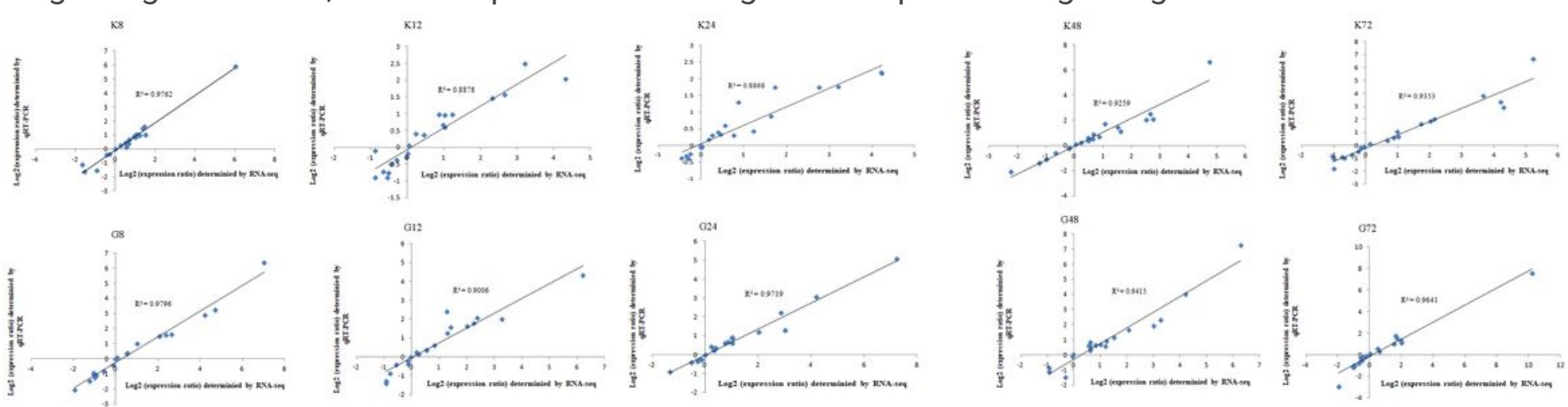
Figure 5

a Heat map showing DEGs encoding transcription factors (TFs) in Jiangcheng 3A and 9311A. b Venn diagrams showing the overlap of DEGs modulated in two rice varieties; $c$ Venn diagrams showing the overlap of genes up-regulated in the two rice varieties at 8 and $12 \mathrm{~h}$ post inoculation.

A

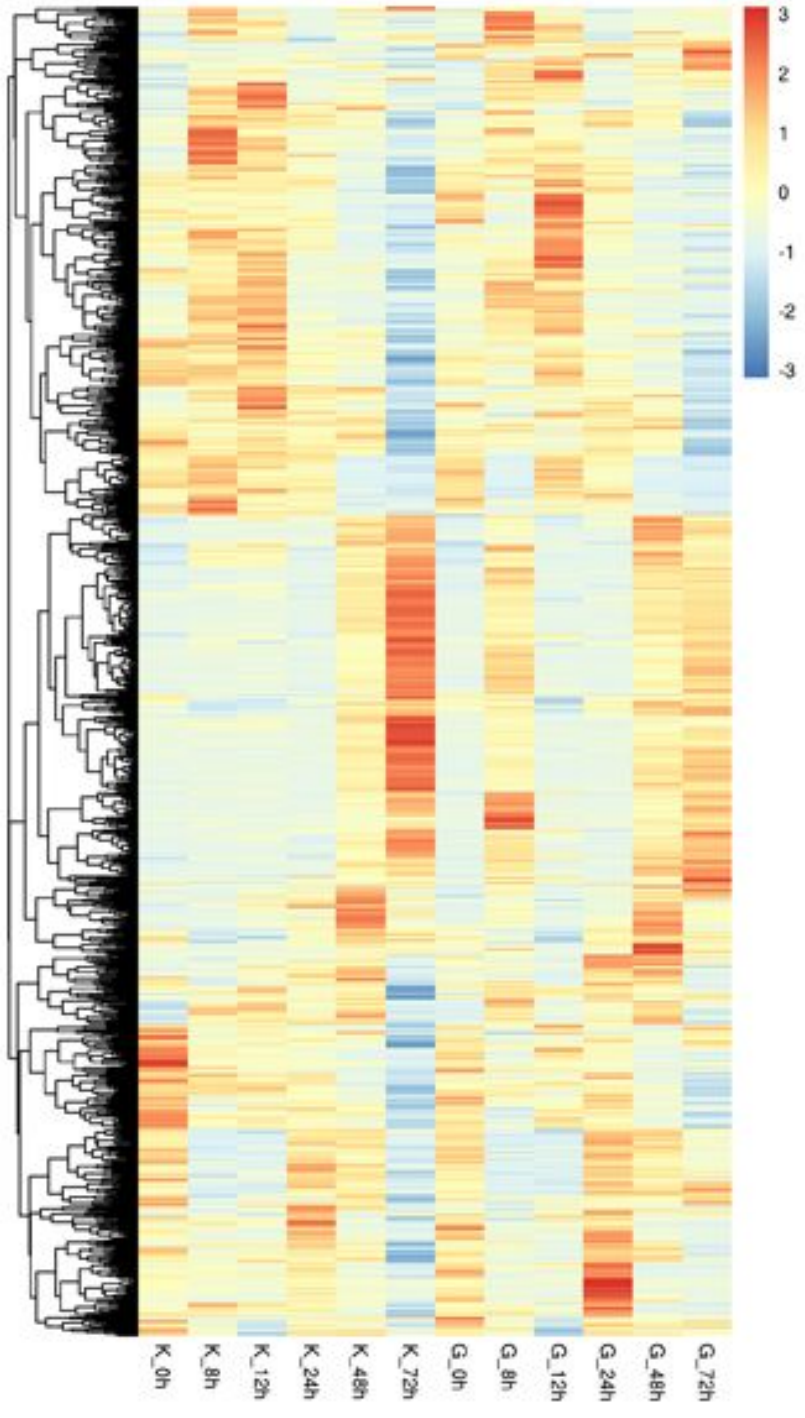

B

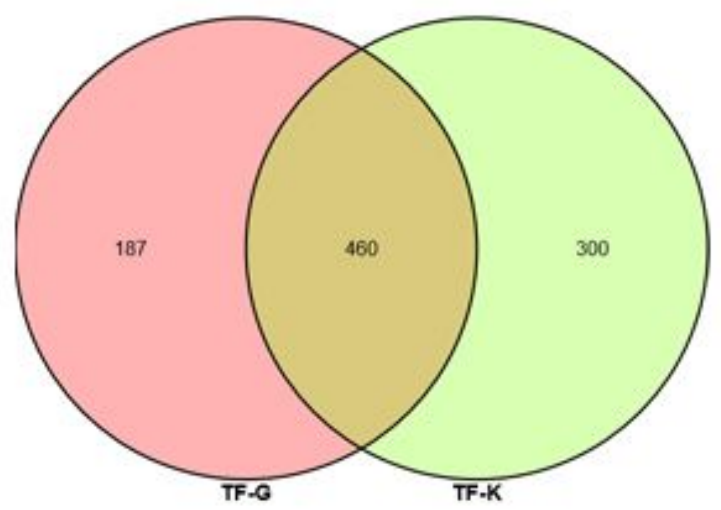

$\mathrm{C}$

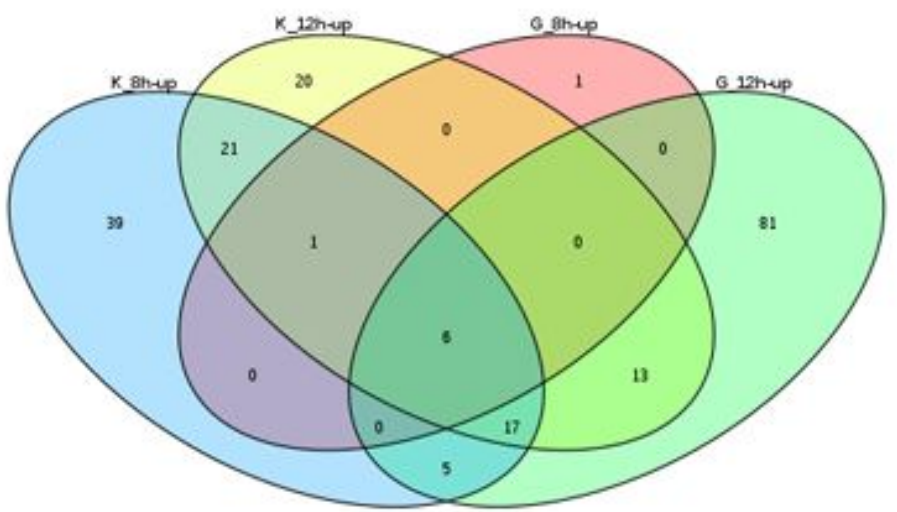

Figure 6

Verification of RNA-Seq data of 21 genes by qRT-PCR. Log2 values of expression ratios (inoculated/mockinoculated) of genes obtained by RNA-Seq (X-axis) were plotted against those obtained by qRT-PCR ( $\mathrm{Y}$ axis). Dpi:days post inoculation.

\section{Supplementary Files}


This is a list of supplementary files associated with this preprint. Click to download.

- TableS12.xlsx

- Tables2.xlsx

- TableS10.xlsx

- Tables5.xlsx

- Tables6.xlsx

- Tables1.xlsx

- TableS11.xlsx

- Tables9.xlsx

- Tables8.xIsx

- Tables7.xlsx

- SupplementaryFig.docx

- Tables4.xIsx

- TableS3.xIsx 